Revista Eletrônica de Direito Processual - REDP.

Rio de Janeiro. Ano 13. Volume 20. Número 1. Janeiro a Abril de 2019

Periódico Quadrimestral da Pós-Graduação Stricto Sensu em Direito Processual da UERJ

Patrono: José Carlos Barbosa Moreira (in mem.). ISSN 1982-7636. pp. 250-287

www.redp.uerj.br

\title{
POLÍTICAS PÚBLICAS E JUDICIÁRIO: A NECESSIDADE DE \\ APRIMORAMENTO DO SISTEMA PROCESSUAL DE TUTELA COLETIVA \\ BRASILEIRO VOLTADO AO CONTROLE JURISDICIONAL DE POLÍTICAS \\ PÚBLICAS ${ }^{1}$
}

\author{
PUBLIC POLICY AND THE JUDICIARY: THE NEED FOR IMPROVEMENT OF \\ THE BRAZILIAN PROCESS SYSTEM OF COLLECTIVE ACTIONS ADDRESSED \\ TO THE JURISDICTIONAL CONTROL OF PUBLIC POLICIES
}

Leandro Ferreira Bernardo

\begin{abstract}
Doutor em Direito pela Faculdade de Direito da Universidade de São Paulo. Professor em cursos de graduação e pós graduação. Procurador federal/AGU. São Paulo. SP. E-mail: leandrofbernardo@hotmail.com
\end{abstract}

RESUMO: O presente texto tem por objeto realizar uma análise crítica-propositiva do sistema processual de tutela coletiva voltada à intervenção e controle do judiciário sobre as políticas públicas, sobretudo a partir das limitações constatadas no modelo vigente, que o torna insuficiente para dar conta da complexa realidade atual, caracterizada pela expansão das demandas da sociedade por acesso aos direitos fundamentais e consequente elevação do número de litígios levados ao judiciário para garantir a efetivação daqueles direitos. A análise proposta se fundamentará, essencialmente, em um estudo do direito processual, com o devido diálogo com outros campos do saber, tais como os direitos humanos, direito constitucional, direito administrativo, ciência política, sociologia direito, a fim de apontar possíveis caminhos de superação dos limites constatados.

PALAVRAS-CHAVE: política pública; intervenção do judiciário; tutela coletiva de direitos; reforma do sistema; acesso à justiça.

\footnotetext{
${ }^{1}$ Artigo recebido em 03/04/2018 e aprovado em 13/11/2018.
} 
Revista Eletrônica de Direito Processual - REDP.

Rio de Janeiro. Ano 13. Volume 20. Número 1. Janeiro a Abril de 2019

Periódico Quadrimestral da Pós-Graduação Stricto Sensu em Direito Processual da UERJ

Patrono: José Carlos Barbosa Moreira (in mem.). ISSN 1982-7636. pp. 250-287

www.redp.uerj.br

ABSTRACT: The purpose of this article is to present a critical-propositional analysis of the collective actions system addressed at judicial control over public policies, especially based on the limitations found in the current model, which makes it insufficient to deal with the current complex reality. This reality, by the way, is characterized by the expansion of society's demands for access to fundamental rights and the consequent increase in the number of disputes brought before the judiciary to guarantee the realization of those rights. The proposed analysis will be based essentially on a study of procedural law, with due dialogue with other fields of knowledge, such as human rights, constitutional law, administrative law, political science, law sociology, in order to point out possible ways to overcoming the limits.

KEYWORDS: public policy; jurisdictional control; collective actions system; reform of the system; access to justice.

\section{INTRODUÇÃO}

A intervenção do Poder Judiciário sobre as outras funções estatais chegou, na atualidade, a níveis impensáveis, quando se compara com realidade de décadas pretéritas. Sobretudo a partir do surgimento da Constituição da República de 1988, que criou um extenso rol de direitos fundamentais em favor da sociedade e uma ampla gama de obrigações direcionadas ao poder público para sua implementação, cada vez mais o judiciário tem sido chamado a interferir sobre as políticas públicas, inclusive sobre temas que tradicionalmente eram considerados sujeitos exclusivamente à discricionariedade do administrador público.

Representa debate de grande atualidade - que ainda não parece possuir uma clara definição - a delimitação de quais seriam os limites daquela atuação do judiciário sobre questões comumente entendidas como reservadas ao âmbito de atuação das autoridades políticas, sobretudo naqueles casos em que a omissão ou má execução das atividades por parte do legislador e do governante - em todos os níveis - tem como consequência prejuízos diretos à população.

Contudo, o presente texto não busca discutir a extensão de tais limites. Em vez disso, esse trabalho tem por objetivo analisar a adequação do sistema jurídico-processual 
Revista Eletrônica de Direito Processual - REDP.

Rio de Janeiro. Ano 13. Volume 20. Número 1. Janeiro a Abril de 2019

Periódico Quadrimestral da Pós-Graduação Stricto Sensu em Direito Processual da UERJ

Patrono: José Carlos Barbosa Moreira (in mem.). ISSN 1982-7636. pp. 250-287

www.redp.uerj.br

atualmente vigente diante da atual realidade, em que o judiciário tem sido chamado, cada

vez mais, a exercer o controle sobre as mais diversas políticas públicas.

Dentro dessa análise crítica do sistema processual, merecerá especial atenção o sistema de tutela coletiva de direitos construído sobretudo a partir da década de 1980 e a suas possíveis limitações para dar conta da realidade ora apresentada.

Em sequência, apresentadas as deficiências do sistema posto, serão apontadas possíveis proposições que poderiam orientar futuras alterações legislativas a fim de garantir uma maior organização da intervenção judicial sobre políticas as públicas. As propostas apresentadas visam apresentar saídas possíveis para novos problemas que, no atual sistema processual, encontram dificuldade de solução ${ }^{2}$.

Em uma perspectiva mais ampla, busca-se apontar caminhos que permitam uma maior efetividade do Direito, a partir da possibilidade de um diálogo qualificado entre judiciário e demais funções estatais, sem que resulte, ao final, um desatendimento da sociedade ${ }^{3}$.

Enfim, o presente trabalho parte da premissa de que uma análise crítica-propositiva do sistema processual de tutela coletiva de direitos é fundamental para se poder apontar para possíveis caminhos na superação do modelo em vigor e a implementação de um instrumento mais adequado para o exercício de controle e intervenção em políticas públicas pelo Poder Judiciário e, consequentemente, para que essa fundamental função estatal possa desempenhar seu mister nesse atual contexto ${ }^{4}$.

\footnotetext{
${ }^{2}$ GRINOVER, Ada Pellegrini. Ensaio sobre a processualidade: fundamentos para uma nova teoria geral do processo, p. 3. A autora busca apresentar uma nova visão do direito processual, tendo como norte "o estudo do direito processual a partir da análise de um campo específico da realidade social para determinar a melhor resposta processual para a crise de direito em jogo. Isso significa examinar os conflitos que existem na sociedade, para chegar à tutela processual adequada".

${ }^{3}$ BITTAR, O direito na pós-modernidade. 3. Ed. modificada e atualizada. São Paulo: Atlas, 2014. O direito na pós-modernidade. 3. ed. modificada e atualizada. São Paulo: Atlas, 2014, p. 5: "O diagnóstico do tempo presente contido nesta reflexão serve para indicar que da crise e da falta de eficácia do direito acabam nascendo patologias sociais que colocam o Estado Social e Democrático de Direito e a ordem jurídica na berlinda entre civilização e barbárie".

${ }^{4}$ PASSOS, José Joaquim Calmon de. Direito, poder, justiça e processo: julgando os que nos julgam. Rio de Janeiro: Forense, 2000, p. 3 "Quando blateramos contra o modo pelo qual as coisas se passam, hoje, no Brasil, em termos de Poder Judiciário, não estamos enlameando este espaço da atividade pública, fundamental para a saúde democrática de qualquer povo, antes colocamo-la em lugar privilegiado, fazendo-a objeto de nosso cuidado, porque desejamos vê-la livre de cair em tentação e liberta de todo o mal. Amém".
} 
Revista Eletrônica de Direito Processual - REDP.

Rio de Janeiro. Ano 13. Volume 20. Número 1. Janeiro a Abril de 2019

Periódico Quadrimestral da Pós-Graduação Stricto Sensu em Direito Processual da UERJ

Patrono: José Carlos Barbosa Moreira (in mem.). ISSN 1982-7636. pp. 250-287

www.redp.uerj.br

\section{POLÍTICAS PÚBLICAS NO BRASIL}

Antes mesmo de adentrar no debate central proposto no presente texto, cumpre, inicialmente, apontar para a definição daquilo que se entende por políticas públicas. Para os fins do presente trabalho, adota-se o conceito apresentado por Maria Paula Dallari Bucci, para quem política pública:

[...] é programa de ação governamental. Seu núcleo de sentido reside na ação governamental, isto é, o movimento que se dá à máquina pública, conjugando competências, objetivos e meios estatais, a partir do impulso do governo. A apresentação da política se materializa num arranjo institucional, conjunto de iniciativas e medidas articulado por suportes e formas jurídicos diversos ${ }^{5}$.

As políticas públicas estão diretamente relacionadas às demandas sociais dirigidas ao poder público pela sociedade. Dentre outros fatores, o desenvolvimento do Estado moderno, sobretudo a partir da do período posterior às revoluções liberais do século XVIII ${ }^{6}$ em especial com a construção do constitucionalismo - e, mais recentemente, com a construção e consolidação de um sistema de proteção de direitos humanos e de uma agenda mínima de direitos fundamentais - sobretudo depois da segunda metade do século passado - favoreceu a exigência crescente pelo atendimento de tais demandas pelo Estado ${ }^{7}$.

No caso do Brasil, país em que grande parte da sociedade se encontra nas camadas mais pobres e marginalizadas, a atuação do poder público se mostra mais premente. Nesse aspecto, cumpre apontar um fundamento relevante justificador de uma maior responsabilidade social do Estado brasileiro, que diz respeito à constatação de que, ao longo da história de formação do país, o poder público foi um importante instrumento de marginalização da sociedade e de manutenção de privilégios em favor de camadas restritas da sociedade.

\footnotetext{
${ }^{5}$ BUCCI, Maria Paula Dallari. Fundamentos para uma teoria jurídica das políticas públicas. São Paulo: Saraiva, 2013, p. 32-33.

${ }^{6}$ HOBSBAWM, Eric J. Nações e nacionalismo desde 1780: programa, mito e realidade. Tradução: Maria Celia Paoli \& Anna Maria Quirino. Rio de Janeiro: Paz e Terra, 1990, p. 101.

${ }^{7}$ DALLARI, Direitos humanos e cidadania. 2. ed. reform. São Paulo: Moderna, 2004, p. 12.
} 
Revista Eletrônica de Direito Processual - REDP.

Rio de Janeiro. Ano 13. Volume 20. Número 1. Janeiro a Abril de 2019

Periódico Quadrimestral da Pós-Graduação Stricto Sensu em Direito Processual da UERJ

Patrono: José Carlos Barbosa Moreira (in mem.). ISSN 1982-7636. pp. 250-287

www.redp.uerj.br

Lembre-se que no território brasileiro, a partir de 1500 e nos séculos seguintes, a escravidão, sobretudo da população negra, fez-se presente em todo o território ${ }^{8}$. O poder público não somente tolerou o sistema escravagista, como foi grande incentivador e garantidor da manutenção da prática de submissão da população africana para cá trazida e seus descendentes.

Esse perverso sistema de negação de direitos ainda deixa claras marcas na geração de desigualdades dentro do país, a partir do critério étnico, como é possível observar com clareza nas estatísticas que apontam os quantitativos de população mais pobre, menores níveis de escolaridade, maior presença no universo carcerário, maior quantitativo de vítimas do aparelho repressivo do Estado etc ${ }^{9}$.

Os povos indígenas são outro importante elemento formador da sociedade nacional que, ao longo do processo de colonização e de formação do estado brasileiro, foram vítimas da omissão do poder público em sua proteção e, mais do que isso, da ação prejudicial do Estado sobre seus direitos ${ }^{10}$.

Outros grupos mais vulneráveis e que se encontram dispersos na sociedade carecem, em alguma medida, de políticas públicas específicas a fim de garantir condições mínimas de sobrevivência e dignidade. Crianças, idosos, mulheres, portadores de deficiência são exemplos de coletividades que, aos poucos, têm visto a garantia de seus direitos especiais inseridas dentre as obrigações do poder público, ao implementar suas políticas públicas sociais gerais - educação, saúde, segurança, dentre outras ${ }^{11}$.

As demandas de políticas públicas não encontram limites objetivos predefinidos, eis que dependem da experiência, das necessidades e de condições de seu atendimento em cada

\footnotetext{
${ }^{8}$ CARDOSO, Fernando Henrique. Capitalismo e escravidão no Brasil meridional: o negro na sociedade escravocrata do Rio Grande do Sul. Rio de Janeiro: Civilização Brasileira, 2003, p.225. Mesmo no sul do Brasil foi intenso o uso da mão-de-obra escrava e a estrutura econômica e política local era fortemente construída sobre tal sistema, como constata o sociólogo Fernando Henrique Cardoso na obra acima.

${ }^{9}$ FERNANDES, Florestan. O negro no mundo dos brancos. 2. ed. revista. São Paulo: Global, 2007.

${ }^{10}$ CUNHA, Manuela Carneiro da. História dos índios no Brasil. São Paulo: Companhia das Letras; Secretaria Municipal de Cultura; FAPESP, 1992.

${ }^{11}$ COMPARATO, Fábio Konder. Ensaio sobre o juízo de constitucionalidade de políticas públicas. In: Revista de Informação Legislativa, Brasília a. 35 n. 138 abr./jun. 1998. Disponível em: <http://www2.senado.leg.br/bdsf/>. Acesso em: 24 jan. 2017, p. 45. Nesse sentido da existência de políticas públicas específicas e outras mais gerais, afirma Comparato que "As Constituições do moderno Estado Dirigente impõem, todas, certos objetivos ao corpo político como um todo - órgãos estatais e sociedade civil. Tais objetivos podem ser gerais ou especiais; estes últimos, obviamente, coordenados àqueles".
} 
Revista Eletrônica de Direito Processual - REDP.

Rio de Janeiro. Ano 13. Volume 20. Número 1. Janeiro a Abril de 2019

Periódico Quadrimestral da Pós-Graduação Stricto Sensu em Direito Processual da UERJ

Patrono: José Carlos Barbosa Moreira (in mem.). ISSN 1982-7636. pp. 250-287

www.redp.uerj.br

sociedade, no tempo e no espaço. Em grande medida suas limitações serão dadas a partir da imposição de restrições naturais ou nas condições de atendimento por parte do Estado ${ }^{12}$.

A busca da inclusão daqueles grupos marginalizados atende a um dos principais desafios do momento atual, que convencionou-se chamar de pós-modernidade ${ }^{13}$, em que há o reconhecimento da existência de uma heterogeneidade social inolvidável - em contrariedade aos postulados assimiliacionistas e de criação de um padrão humano universal propugnados pela modernidade - e, no campo do direito, a uma maior viabilidade de abertura para o conhecimento de peculiaridades sociais locais e a busca da defesa de grupos historicamente excluídos do âmbito de proteção estatal ${ }^{14}$.

A temática envolvendo a implementação das políticas públicas no Brasil ganhou maior adensamento com a promulgação da Constituição da República de 1988, que contemplou um extenso rol de direitos fundamentais, com a correspondente imposição de programas e obrigações a serem implementadas pelo poder público, a fim de dar efetividade àqueles direitos ${ }^{15}$.

Some-se a isso o fato de o país, apesar de ser uma das principais economias do mundo, ainda padecer de grandes dificuldades na redução das desigualdades sociais e ter tido dificuldades em avançar em áreas fundamentais ao desenvolvimento da sociedade, tais como saúde, educação e moradia ${ }^{16}$.

\footnotetext{
${ }^{12}$ PASSOS, José Joaquim Calmon de, op. cit., p. 37.

${ }^{13}$ De acordo com Eduardo Bittar, op. cit., p. 123: "As lutas morais mais gigantescas da pós-modernidade giram em torno da presença de excluídos no mapa da humanidade, excluídos de toda sorte, que pululam em meio às ruas das grandes metrópoles, que se aglomeram em verdadeiras cidadelas independentes que são as favelas, que buscam asilo em países estrangeiros, que atravessam perigosamente fronteiras em busca de socorre em face dos flagelos da guerra etc."

${ }^{14}$ HARVEY, David. Condição pós-moderna: Uma pesquisa sobre as origens da mudança cultural. Tradução: Adail Ubirajara Sobral; Maria Stela Gonçalves. Edições Loyola: São Paulo, 2009. Harvey destina maior atenção a esse componente sociocultural criado pela modernidade consistente na falsa ideia de sociedade universal e que concorreu para a derrocada da pós-modernidade: "O pós-modernismo assinala a morte dessas 'metanarrativas', cuja função terrorista secreta era fundamentar e legitimar a ilusão de uma história humana 'universal'. Estamos agora no processo de despertar do pesadelo da modernidade, com sua razão manipuladora e seu fetiche da totalidade, para o pluralismo retornado do pós-moderno, essa gama heterogênea de estilos de vida e jogos de linguagem que renunciou ao impulso nostálgico de totalizar e legitimar a si mesmo” (p. 19). Cf., também, BAUMAN, Zygmunt. O mal-estar da pós-modernidade. Tradução: Mauro Gama, Cláudia Martinelli Gama. Rio de Janeiro: Zahar, 1998, p. 43.

${ }^{15}$ Segundo, ainda, Maria Paula Dallari Bucci, op. cit., p. 24, a década de 1990 "a temática das políticas públicas ganha presença no universo do direito no Brasil, aspirando à quitação da dívida social, pela realização dos direitos sociais, com o tratamento ambicioso e generoso que lhes conferia a Constituição Federal de 1988".

${ }^{16}$ SILVA, Virgílio Afonso da. O Judiciário e as políticas públicas: entre transformação social e obstáculo à realização dos direitos sociais. In: Cláudio Pereira de Souza Neto \& Daniel Sarmento, Direitos sociais: fundamentação, judicialização e direitos sociais em espécies, Rio de Janeiro: Lumen Juris, 2008, p. 587.
} 
Revista Eletrônica de Direito Processual - REDP.

Rio de Janeiro. Ano 13. Volume 20. Número 1. Janeiro a Abril de 2019

Periódico Quadrimestral da Pós-Graduação Stricto Sensu em Direito Processual da UERJ

Patrono: José Carlos Barbosa Moreira (in mem.). ISSN 1982-7636. pp. 250-287

www.redp.uerj.br

Diante de tal contexto, o período posterior à Constituição de 1988 trouxe um aumento do alcance dos debates sobre as políticas públicas dentro do universo jurídico, em especial acerca da sindicabilidade das políticas públicas ou da omissão na sua implementação pelo judiciário a partir da sua constitucionalidade, diante da comumente constatada ineficiência de atuação das funções legislativa e administrativa em seus misteres previstos no texto constitucional $^{17}$.

\section{PODER JUDICIÁRIO E POLÍTICAS PÚBLICAS:}

Nas últimas décadas vem ganhando espaço no direito o desenvolvimento de teorias e de práticas que, sob o pretexto de garantir uma maior eficácia do texto constitucional, têm ampliado a relevância da função jurisdicional dentro do Estado democrático de Direito ${ }^{18}$. Exemplo desse protagonismo político deferido ao judiciário consiste na criação de mecanismos que lhe tem permitido o exercício do controle concentrado de constitucionalidade de leis e atos normativos criados pelas demais funções estatais ${ }^{19}$.

Dentro desse contexto de sobrelevação da relevância do judiciário, discussão de grande vulto nas últimas décadas diz respeito à possibilidade de se buscar na função jurisdicional a implementação das políticas públicas, sobretudo diante da dificuldade do Estado em implementar os programas previstos na Constituição e diante da ampliação dos direitos reconhecidos como fundamentais ${ }^{20}$.

$\mathrm{Na}$ atualidade tem sido reconhecida em favor do judiciário a legitimidade de intervir sobre as demais funções estatais a fim de garantir a implantação de políticas públicas ${ }^{21}$. É sob tal perspectiva que Ada Pelegrini Grinover inclui o Judiciário entre as funções estatais responsáveis pela implementação de políticas públicas:

Entende-se por políticas públicas o conjunto de instrumentos necessários utilizado pelo Estado para propiciar a fruição dos direitos sociais de

\footnotetext{
${ }^{17}$ COMPARATO, op. cit., p. 44.

${ }^{18}$ Nesse sentido, vide BARBOZA, Estefânia Maria de Queiroz \& KOZICKI, Katya. Judicialização da política e controle judicial de políticas públicas. Revista Direito GV, [S.1.], v. 8, n. 1, p. 059-085, jan. 2012. ISSN 2317-6172. Disponível

em: <http://bibliotecadigital.fgv.br/ojs/index.php/revdireitogv/article/view/23970/22728>. Acesso em: 01 mar. 2018, p. 59-60.

${ }^{19}$ BUCCI, op. cit., p. 73.

${ }^{20}$ BARBOZA \& KOZICKI, op. cit., p. 60. Cf., também, COMPARATO, op. cit., p. 47.

${ }^{21}$ COMPARATO, op. cit., p. 46: "Afastemos, antes de mais nada, a clássica objeção de que o Judiciário não tem competência, pelo princípio da divisão de Poderes, para julgar "questões políticas"”.
} 
Revista Eletrônica de Direito Processual - REDP.

Rio de Janeiro. Ano 13. Volume 20. Número 1. Janeiro a Abril de 2019

Periódico Quadrimestral da Pós-Graduação Stricto Sensu em Direito Processual da UERJ

Patrono: José Carlos Barbosa Moreira (in mem.). ISSN 1982-7636. pp. 250-287

www.redp.uerj.br

natureza prestacional previstos na Constituição. Todos os poderes do

Estado são responsáveis pelas Políticas Públicas. O Legislativo as formula mediante leis e outros atos normativos; o Executivo as planeja e executa.

Mas se houver omissão ou incorreção na atuação de qualquer dos Poderes (ou seja, na formulação ou execução das políticas públicas), o Judiciário sempre a posteriori e só quando provocado - exerce o seu controle, que nada mais representa do que um controle da constitucionalidade, pois os direitos sociais são assegurados pela Constituição, e a inexistência ou incorreção de uma política pública, em última análise, vulnera a Constituição $0^{22}$.

Nesse âmbito de atuação do judiciário sobre as políticas públicas ocupa lugar de especial relevância, pelo seu potencial transformador, as chamadas decisões estruturais (structural injunctions), que correspondem a provimentos judiciais de âmbito coletivo e que, nas palavras de Marcella Ferraro, "visam a reformar instituições, já que o modo como operam, em razão de suas práticas e dinâmicas, acarreta violações de direitos"23.

Os limites dessa intervenção ainda carecem de uma melhor definição e tem variado de país para país, a depender de fatores locais, tais como a atuação do Legislativo e Executivo, condições sociais, direitos reconhecidos como fundamentais pelas Constituições, dentre outros.

No Brasil, as posições que buscam justificar uma maior amplitude no controle judicial sobre as políticas públicas fundamentam-se, geralmente, na necessidade de se garantir maior eficácia possível aos direitos fundamentais ${ }^{24}$. De outro lado, parte da doutrina reconhece a

\footnotetext{
${ }^{22}$ FISS, Owen. The law as It could be. New York and London: New York University Press, 2003, p. 8: "A função de um juiz é dar concreto significado e aplicação para nossos valores constitucionais. Uma vez que percebamos ser esta a função judicial em casos de admitidas falhas legislativas, então nós somos levados a imaginar o por quê a performance desta função é condicionada em primeiro lugar pela falha legislativa". CF., também, GRINOVER, op. cit., p. 43, e BARBOZA \& KOZICKI, op. cit., p. 59.

${ }^{23}$ FERRARO, Marcella Pereira. Do processo bipolar a um processo coletivo-estrutural. 2015. 224 f. Dissertação (Mestrado em Direito das Relações Sociais) - Universidade Federal do Paraná, Curitiba, 2015. Disponível em: <https://acervodigital.ufpr.br/handle/1884/39322>. Acessado em: 21 mar. 2018. Sobre a origem das structural injunctions na segunda metade do século passado no direito norte-americano, vide FISS, op. cit., p. 8. No referido texto, FISS contrapõe ao tradicional modelo das "adjudication", referente ao sistema de litigância individual, as chamadas 'structural reforms', surgidas no sistema norte-americano na década de 1950, com o caso Brown vs. Board education. Para tanto, as chamadas structural injunctions (ordem que determina a proibição ou impõe uma ação ao poder público) foram determinantes. Como consequência, vislumbrou-se um importante instrumento na construção das instituições públicas.

${ }^{24}$ BARBOZA \& KOZICKI, op. cit., p. 73.
} 
Revista Eletrônica de Direito Processual - REDP.

Rio de Janeiro. Ano 13. Volume 20. Número 1. Janeiro a Abril de 2019

Periódico Quadrimestral da Pós-Graduação Stricto Sensu em Direito Processual da UERJ

Patrono: José Carlos Barbosa Moreira (in mem.). ISSN 1982-7636. pp. 250-287

www.redp.uerj.br

necessidade de se estabelecer balizas limitadoras dessa intervenção judicial, a fim de que se garanta maior respeito à atuação dos poderes legitimados pela vontade popular e que teriam melhores condições de apontar e efetivar as demandas mais prementes da sociedade ${ }^{25}$.

Outro argumento presente e que fortalece a necessidade de se criar limites ou procedimentos mais rígidos na atuação judicial sobre as políticas públicas diz respeito à constatação de vários problemas decorrentes da atuação casuística do judiciário nessa temática, com a criação de soluções limitadas aos casos concretos submetidos à apreciação judicial.

Em situações como essas, o cumprimento de uma determinação judicial casuística pode vir a dificultar o planejamento e a efetivação de uma política pública em níveis mais amplos, com o comprometimento de um percentual relevante da verba orçamentária destinada à área sob análise. Eventual descompasso entre a atuação casuística do judiciário e a gestão da política pública exercida pelo Estado-administração se torna ainda mais dramática diante do cenário atual, de severas restrições orçamentárias ${ }^{26}$.

A realidade contemporânea tem permitido constatar que, em muitos outros casos, a decisão judicial não se ampara em fundamentos e critérios superiores àqueles que fizeram o Legislativo e a Administração Pública optarem por caminho diverso na implantação de determinada política pública.

Acerca dos limites interpretativos e de aplicação do direito por parte do judiciário, relevante destacar que, ao contrário do que muitas vezes se imagina, a criação de uma ampla liberdade em favor do judiciário não traz como resultado lógico um incremento dos direitos fundamentais. Pelo contrário, observa-se que em muitos casos importantes a ausência de balizas interpretativas claras e objetivas, sobretudo no âmbito do STF, tem redundado na restrição de direitos fundamentais previstos na Constituição.

Apenas a título ilustrativo, apenas no âmbito do Supremo Tribunal Federal, cite-se alguns recentes julgados que representam flagrante restrição de direitos fundamentais previstos no texto constitucional: (i) a flexibilização da garantia da presunção de inocência no âmbito processual penal (art. $5^{\circ}$, LVII) e a permissão de prisão do condenado

\footnotetext{
${ }^{25}$ BUCCI, op. cit., p. 50-51.

${ }^{26}$ Nesse contexto, verifica-se que a União tem passado nos últimos anos por grave crise fiscal, com arrecadação insuficiente para dar conta dos gastos previstos (vide Lei orçamentária de 2018 - Lei 13.587/18. Para enfrentar os problemas envolvendo a questão fiscal, foi promulgada em 15 de dezembro de 2016 a E.C. 95, que instituiu um "novo regime fiscal" e que prevê sérias limitações nos gastos públicos para os próximos anos.
} 
Revista Eletrônica de Direito Processual - REDP.

Rio de Janeiro. Ano 13. Volume 20. Número 1. Janeiro a Abril de 2019

Periódico Quadrimestral da Pós-Graduação Stricto Sensu em Direito Processual da UERJ

Patrono: José Carlos Barbosa Moreira (in mem.). ISSN 1982-7636. pp. 250-287

www.redp.uerj.br

criminalmente em segunda instância, independentemente do trânsito em julgado da sentença penal condenatória ${ }^{27}$; (ii) a redução da garantia dos direitos dos povos indígenas às suas terras, com a criação da dita teoria do chamado "marco temporal”, que impõe como condição necessária para a demarcação de terra indígena, em resumo, que somente possam ser reconhecidas como terras tradicionalmente ocupadas pelos povos indígenas aquelas que se encontravam em sua posse no momento da promulgação da atual Constituição da República $^{28}$; (iii) o reconhecimento da constitucionalidade dos principais dispositivos da Lei 12.651/12, o novo Código Florestal, apesar dos flagrantes retrocessos que traz à preservação do meio ambiente e a redução do valor normativo do texto constitucional protetivo do meio ambiente (art. 225 da Constituição da República) ${ }^{29}$.

A referida ausência de clareza nos limites interpretativos da Constituição e legislação pátrias por parte do juiz-intérprete, em especial no âmbito do STF, segundo Eros Roberto Grau, tem convertido o Poder Judiciário em um "produtor de insegurança" ${ }^{30}$. Torna-se crucial, p. ex., ao intérprete/julgador explicitar a premissa teórica no sopesamento dos princípios e direitos postos em jogo no julgamento a fim de se evitar uma interpretação/aplicação arbitrária do texto constitucional, como alertado por Eros Roberto Grau, para quem "a ponderação entre princípios tem sido operada, pela jurisprudência e pela doutrina, discricionariamente, à margem da interpretação/aplicação do direito, conduzindo à incerteza jurídica" ${ }^{\text {31. }}$.

\footnotetext{
${ }^{27}$ O STF, em 2016, por ocasião do julgamento do leading case ARE 964246, em sede de repercussão geral, sob a relatoria do Ministro Teori Zavascki, definiu, a seguinte tese 925: "A execução provisória de acórdão penal condenatório proferido em grau recursal, ainda que sujeito a recurso especial ou extraordinário, não compromete o princípio constitucional da presunção da inocência".

${ }^{28}$ Tal entendimento surgiu, inicialmente no âmbito do STF, por ocasião do julgamento da Pet 3.388, Rel. Min. Carlos Britto, DJe de 1\%/7/2010, no conhecido processo envolvendo a demarcação da terra indígena Raposa Serra do Sol. De acordo com o entendimento ali firmado, somente pode ser considerada terra indígena passível de demarcação aquela ocupada por indígenas no momento da promulgação da atual Constituição da República, ou seja, em 05 de outubro de 1988. Digno de nota, por outro lado, que o próprio STF tem flexibilizado a tese do "marco temporal" diante da constatação da ocorrência de "esbulho renitente", que consiste, nas palavras do Ministro Teori Zavaski, por ocasião do julgamento do Agravo Regimental no RE com Agravo 803.462, sob sua relatoria, em acórdão publicado em 09-12-2014, na "situação de efetivo conflito possessório que, mesmo iniciado no passado, ainda persista até o marco demarcatório temporal atual (vale dizer, a data da promulgação da Constituição de 1988), conflito que se materializa por circunstâncias de fato ou, pelo menos, por uma controvérsia possessória judicializada".

${ }^{29}$ Sobre o tema, o STF concluiu, em 28 de fevereiro de 2018, o julgamento das ADIs 4901, 4902 e 4903, 4937 e Ação Declaratória de Constitucionalidade (ADC) 42.

30 GRAU, Ero Roberto. Por que tenho medo de juízes: (a interpretação/aplicação do direito e os princípios). 8. ed. refundida do Ensaio e discurso sobre a interpretação/aplicação do direito. São Paulo: Malheiros, 2017, p. 18.

31 GRAU, op. cit., p. 117. Segundo defende o referido autor, op. cit., p. 119, a ponderação não poderia ser utilizada na operação de interpretação/aplicação dos princípios, por serem regras jurídicas, e não valores.
} 
Revista Eletrônica de Direito Processual - REDP.

Rio de Janeiro. Ano 13. Volume 20. Número 1. Janeiro a Abril de 2019

Periódico Quadrimestral da Pós-Graduação Stricto Sensu em Direito Processual da UERJ

Patrono: José Carlos Barbosa Moreira (in mem.). ISSN 1982-7636. pp. 250-287

www.redp.uerj.br

Causa preocupação a constatação de que a adoção dessa liberdade interpretativa tem

representado, na prática, em muitos casos, o afastamento do judiciário - incluindo-se aí especialmente a nossa Corte Constitucional - da norma legislada, bem como de doutrina e jurisprudência já consolidadas e reiteradamente observadas, sobretudo aquelas que têm prestigiado o princípio da máxima efetividade dos direitos fundamentais previstos na Constituição ${ }^{32}$.

Sobre a necessidade de restrição, no plano hermenêutico, da atividade do intérprete da lei, afirma Lênio Streck:

[...] a afirmação 'a norma é (sempre) produto da interpretação do texto', ou que o 'intérprete sempre atribui sentido (Sinngebung) ao texto', nem de longe pode significar a possibilidade deste - o intérprete - poder 'dizer qualquer coisa sobre qualquer coisa', atribuindo sentidos de forma arbitrária aos textos, como se texto e norma estivessem separados (e, portanto, tivessem 'existência' autônoma) ${ }^{33}$.

Há que se observar que a incerteza gerada a partir da interpretação/aplicação do sistema normativo de forma descontrolada contribui para o aumento do número de litígios

\footnotetext{
${ }^{32}$ SARLET, Ingo Wolfgang. A eficácia dos direitos fundamentais. 6. ed. Ver. atual, e ampl. Porto Alegre: Livraria do Advogado Editora; 2006, p. 271. Apenas a título ilustrativo, cite-se exemplo recente em que o STF adotou, como fundamento de julgamento, a existência de obediência ao referido princípio, na ADI 3943, Relator(a): Min. Cármen Lúcia, Tribunal Pleno, d. j. 07/05/2015, DJe-154. No referido processo, o Tribunal afastou a alegação por parte de associação de integrantes do Ministério Público no sentido da ilegitimidade da Defensoria Pública para o ajuizamento de Ações Civis Públicas na tutela de interesses transindividuais e individuais homogêneos. Cf., também, CANOTILHO, J. J. Gomes. Direito Constitucional e Teoria da Constituição. 7. ed. Coimbra: Almedina, 1997, p. 1224. De acordo com Canotilho, no texto acima, tal princípio da máxima efetividade "pode ser formulado da seguinte maneira: a uma norma constitucional deve ser atribuído o sentido que maior eficácia lhe dê. E um princípio operativo em relação a todas e quaisquer normas constitucionais, e embora a sua origem esteja ligada à tese da atualidade das normas programáticas (...), é hoje sobretudo invocado no âmbito dos direitos fundamentais (no caso de dúvidas deve preferir-se a interpretação que reconheça maior eficácia aos direitos fundamentais)".

${ }^{33}$ STRECK, Lênio Luiz. Hermenêutica jurídica e(m) crise: uma exploração hermenêutica da construção do direito. 7. ed. rev. e atual. Porto Alegre: Livraria do Advogado Editora, 2007, p. 316/317.

Acerca da tradição brasileira de negar validade ao comando constitucional, afirma Pontes de Miranda, ao interpretar a Constituição da República de 1967: "Seria preciso que se evitasse a justiça de classe, a justiça reacionária. [...]. No Brasil, tal reacionarismo foi mais grave [quando comparado ao que se deu nos Estados Unidos], porque não se dirigiu contra as leis sociais em nome de Constituição abstinente, omissa, quase oca, porem contra a Constituição mesma, ameaçada de falir, dizíamos nós em 1935, e por fim falida, por culpa do próprio judiciário e administrativo, de não na aplicar" (PONTES DE MIRANDA, Francisco C. Comentários à Constituição de 1967 com a emenda n. 1, de 1969. Tomo IV (arts. 118-153, § $1^{\circ}$ ). São Paulo: Editora Revista dos Tribunais, 1970, p. 2). Cf., também, PASSOS, José Joaquim Calmon de, p. 70. De acordo com Calmon de Passos: "O ganho civilizatório que é o Estado de Direito Democrático impõe seja pensado o processo de produção do Direito em consonância com ele”. Cf., também, BUCCI, op. cit., p. 106.
} 
Revista Eletrônica de Direito Processual - REDP.

Rio de Janeiro. Ano 13. Volume 20. Número 1. Janeiro a Abril de 2019

Periódico Quadrimestral da Pós-Graduação Stricto Sensu em Direito Processual da UERJ

Patrono: José Carlos Barbosa Moreira (in mem.). ISSN 1982-7636. pp. 250-287

www.redp.uerj.br

gerados no seio do judiciário, em especial aqueles que buscam o exercício de controle sobre as políticas públicas.

De qualquer modo, a existência de um número elevado de litígios envolvendo no polo passivo entes públicos na busca de implementação de políticas públicas e a diversidade de entendimentos sobre os limites da atuação do judiciário nessa seara bem demonstram a atualidade e relevância do tema ${ }^{34}$.

Por outro lado, o crescente quantitativo de ações judiciais espalhadas pelos mais diversos foros e tribunais ${ }^{35}$, bem como a baixa resolutividade dos processos de forma conciliatória $^{36}$, permitem vislumbrar a existência da grandeza do desafio e dificuldade que representa para a estrutura do judiciário a tarefa de buscar atender, de forma satisfatória, a garantia dos direitos fundamentais previstos na Constituição e direcionados ao poder público.

\subsection{A intervenção judicial sobre as políticas públicas e as limitações do sistema} processual vigente

O judiciário, segundo a doutrina jurídica e jurisprudência correntes, como poder garantidor dos direitos fundamentais, exerceria um ativo papel na implementação das políticas públicas ${ }^{37}$. Diante do reconhecimento da possibilidade de intervenção do judiciário sobre as políticas públicas levadas a cabo pelo Estado, a discussão seguinte diz respeito à identificação de reais dificuldades nessa atuação e, consequentemente, o apontamento de balizas e propostas, a fim de se garantir uma maior uniformidade na atuação da função jurisdicional e, portanto, maior segurança jurídica para o cidadão e para a administração pública, quando essa se vê na obrigação de implantar as políticas públicas na forma determinada judicialmente.

34 CNJ. 100 maiores litigantes. Disponível em: < http://www.cnj.jus.br/images/pesquisasjudiciarias/pesquisa_100_maiores_litigantes.pdf $>$. Acessado em: 10 jul. 2011. Nesse relevante estudo, o CNJ elenca os 100 maiores litigantes da justiça brasileira. Ali fica evidenciado um alto quantitativo de demandas envolvendo o poder público, sobretudo em situações em que assume a posição de demandado.

${ }^{35}$ Ibid. O referido estudo realizado pelo Conselho Nacional de Justiça aponta para um aumento anual do total de processos em tramitação no judiciário. Passou-se de pouco mais de 60 milhões em 2009 para cerca de 79,7 milhões em 2016.

${ }^{36}$ CNJ. Justiça em números 2017: ano base 2016. Disponível em: < http://www.cnj.jus.br/programas-eacoes/pj-justica-em-numeros >. Acessado em: 21 mar. 2018. De acordo com o relatório do CNJ - Justiça em Números 2017, o total sentenças homologatórias de acordos nas ações judiciais que tramitaram em 2016 é inferior a $12 \%$.

${ }^{37}$ GRINOVER, op. cit., p. 125. 
Revista Eletrônica de Direito Processual - REDP.

Rio de Janeiro. Ano 13. Volume 20. Número 1. Janeiro a Abril de 2019

Periódico Quadrimestral da Pós-Graduação Stricto Sensu em Direito Processual da UERJ

Patrono: José Carlos Barbosa Moreira (in mem.). ISSN 1982-7636. pp. 250-287

www.redp.uerj.br

Algumas questões práticas surgidas a partir da análise da intervenção judicial sobre as

políticas públicas permitem identificar problemas que tem se tornado comum na atualidade no nosso sistema de justiça. Primeiramente, o já referido aumento do quantitativo de ações, individuais e coletivas, quem tem por pano de fundo a intervenção do judiciário sobre as políticas públicas, em especial as de caráter coletivo ${ }^{38}$. Além disso, concessões de liminares com imediato impacto sobre a atuação da administração pública e que acabam sendo, em muitos casos, revogadas, tem se tornado fato comum e que trazem grande transtorno e de quebra de expectativas aos envolvidos (em especial a administração e os indivíduos ou coletividade potencialmente interessada).

Vê-se, da mesma forma, o espraiamento de demandas coletivas idênticas perante juízes potencialmente competentes (em abstrato), de acordo com a legislação em vigor, e aumento da insegurança jurídica daí decorrente. Não é rara nesses casos a coexistência de decisões conflitantes e a necessidade de recorrer às normas processuais (inclusive em nível constitucional) a fim de se conhecer o âmbito de abrangência territorial e de interessados acobertados por essas decisões judiciais.

No tópico a seguir serão apresentados alguns casos concretos e que bem permitem constatar as dificuldades acima apontadas.

\subsection{Exemplos de casos concretos recorrentes de controle e intervenção do} judiciário sobre políticas públicas

A fim de dar maior concretude à discussão ora proposta, passa-se a apontar alguns episódios concretos que bem ilustram os problemas decorrentes desse adensamento da atuação do judiciário sobre as políticas públicas sem o adequado balizamento do nosso sistema de justiça.

\section{a) Políticas públicas de educação: CASO ENEM}

Uma relevante seara carente da constante adoção de políticas públicas diz respeito à educação, considerado direito social (art. $6^{\circ}$ ) pela Constituição da República. O texto constitucional destina diversos dispositivos para tratar do tema, p. ex., ao: (i) criar competências legislativas gerais e específicas (art. 22, XXIV e 24, IX); (ii) distribuir entre

\footnotetext{
${ }^{38}$ BARBOZA \& KOZICKI, op. cit., p. 72. Cf, também, BITTAR, op. cit., p. 142.
} 
Revista Eletrônica de Direito Processual - REDP.

Rio de Janeiro. Ano 13. Volume 20. Número 1. Janeiro a Abril de 2019

Periódico Quadrimestral da Pós-Graduação Stricto Sensu em Direito Processual da UERJ

Patrono: José Carlos Barbosa Moreira (in mem.). ISSN 1982-7636. pp. 250-287

www.redp.uerj.br

os entes da federação as atribuições executivas específicas dentro do sistema de educação (art. 30, VI); (iii) criar princípios reitores do ensino (art. 205); (iv) prever ao poder público o exercício de fiscalização sobre instituições privadas de ensino (art. 209); (v) garantir destinação de recursos orçamentários mínimos por cada ente da federação (art. 212); (vi) estabelecer diversos direitos em favor da população (art. 205 e seguintes).

O Exame Nacional do Ensino Médio (Enem) tem se mostrado um importante instrumento de política pública de educação ${ }^{39}$. Possui como objetivo primordial avaliar o desempenho de milhões de estudantes concluintes do ensino médio de todo o país e tem sido acatado como critério de seleção para ingresso em grande parte das instituições de Ensino Superior, públicas ou privadas, e também como critério para acesso a financiamento estudantil (FIES), bolsas de estudo (PROUNI) ${ }^{40}$. O exame do ENEM tem sido realizado uma vez a cada ano $^{41}$ e gera uma mobilização de milhões de pessoas e milhares de instituições a cada ano.

Ocorre que a cada novo exame do ENEM, diversas ações, individuais e coletivas, são movidas contra o poder público federal (MEC, INEP) em diversas localidades e muitas vezes representam uma ameaça à realização dos exames ${ }^{42}$.

Embora com o provável intuito de corrigir problemas do programa do exame nacional, o espraiamento daquelas demandas tem trazido, a cada ano, grande insegurança na organização do exame para o poder público e grave apreensão por parte dos milhões de estudantes que se submetem ao exame, em todo o Brasil.

\footnotetext{
${ }^{39}$ Vide arts. $9^{\circ}$, incisos V, VI e VIII, e 38, § 2º da Lei $\mathrm{n}^{\circ}$ 9.394, de 20 de dezembro de 1996.

${ }^{40}$ Vide sítio do Ministério da Educação na internet: <http://www.mec.gov.br/>. Acessado em: 28 mar. 2018.

${ }^{41}$ Art. $^{\circ}$ da Portaria/MEC n ${ }^{\circ} 468$, de 3 de abril de 2017.

${ }^{42}$ Cite-se como exemplo caso recente em que o Ministério Público Federal do Ceará buscava, pela via judicial, o adiamento de provas do ENEM. Trata-se da Ação Civil Pública sob o nº 0814124-64.2016.4.05.8100, que tramitou na $8^{\text {a }}$ Vara Federal do Ceará, ajuizada em novembro de 2016, buscava o Parquet federal a remarcação das provas já previamente agendadas para todos os alunos do país, sob a alegação de que várias escolas se encontravam ocupadas por movimentos sociais. Após manifestação do Ministério da Educação e do INEP, referida ação foi julgada improcedente pelo juiz competente. Sobre o caso, cf.: AGU. AGU garante realização do Enem e evita prejuízo de $\mathbf{R} \$ \mathbf{7 7 6}$ milhões aos cofres públicos. Disponível em: http://www.agu.gov.br/page/content/detail/id_conteudo/468191. Acessado em: 12 mar. 2018.

Em outra ação civil pública ajuizada perante a mesma justiça federal do Ceará pelo MPF, a Advocacia-Geral da União, na defesa do MEC e INEP, logrou revogar em sede recursal decisão do juízo de primeiro grau que acolhia a pretensão do Parquet para o fim de realizar a imediata divulgação de todas as provas de redação aplicadas, com notas das provas aplicadas acompanhadas dos fundamentos para cada nota, de forma diversa àquela prevista nos regulamentos daquele certame. Sobre esse caso, vide: AGU. AGU derruba decisão que determinava a divulgação das provas de redação de todos os participantes do Enem. Disponível em: http://www.agu.gov.br/page/content/detail/id_conteudo/223913. Acessado em: 12 mar. 2018.
} 
Revista Eletrônica de Direito Processual - REDP.

Rio de Janeiro. Ano 13. Volume 20. Número 1. Janeiro a Abril de 2019

Periódico Quadrimestral da Pós-Graduação Stricto Sensu em Direito Processual da UERJ

Patrono: José Carlos Barbosa Moreira (in mem.). ISSN 1982-7636. pp. 250-287

www.redp.uerj.br

\section{b) Políticas públicas sociais destinadas à moradia da população}

A Constituição da República reconhece também a moradia como direito fundamental de caráter social (art. $6^{\circ}$ ), e, em consequência, impõe o dever ao poder público de promoção daquele direito em favor da população, em especial a mais carente (art. 23, IX).

A administração pública tem sido chamada, pela via judicial, a oferecer programas inclusivos de acesso à moradia às famílias mais carentes, com fundamento no referido direito fundamental à moradia ${ }^{43}$. Muitas vezes a tentativa de atendimento daquela demanda social pela via judicial, de forma individualizada e sem o planejamento global necessário que ela exige, pode redundar num uso ineficiente do dinheiro público.

Sabe-se que o atendimento dessa espécie de política pública não se dá de forma imediata. Pelo contrário, sua efetivação demanda planejamento e um longo prazo de atuação continuada da administração pública até a efetiva disponibilização de moradia à população (incluem-se, aí, etapas como de realização de estudos e projetos prévios, desapropriação de áreas, realização de licitação de obra pública, dentre outras).

\section{c) políticas públicas de segurança pública: a determinação judicial de construção}

\section{de presídios}

A Constituição da República elege a segurança pública como “dever do Estado, direito e responsabilidade de todos" (art. 144). Trata-se, claramente, de um direito fundamental social, também listado no art. $6^{\circ}$ do texto constitucional. Trata-se de uma importante seara de atuação estatal e em relação à qual se observa, nas últimas décadas, um aumento da intervenção e controle por parte do judiciário.

Destacam-se, dentro dessa judicialização das políticas de segurança pública, as ações que, dentre outras coisas, buscam a construção de unidades no sistema penitenciário,

\footnotetext{
${ }^{43}$ Cite-se como exemplo ação possessória sob o número 0001046-90.2008.4.01.3100, movida pela União, em trâmite na $2^{\mathrm{a}}$ Vara Federal de Macapá. Trata-se de caso constatado em ação de reintegração de posse de área pública que a União move no Amapá contra supostos ocupantes irregulares, com o objetivo de retomar o domínio pleno de área integrante do Aeroporto Internacional de Macapá. Após longa tramitação, buscando solucionar o conflito instaurado e garantir direito de moradia às famílias envolvidas, em decisão interlocutória proferida por juiz federal do Amapá, em julho de 2016, determinou à União que desse início à construção de 4985 unidades habitacionais dentro do programa federal "Minha Casa, Minha vida". A referida decisão foi suspensa em sede recursal pelo TRF1, em outubro de 2017, sob o fundamento principal no sentido de que a determinação judicial fugia aos limites da lide (TRF1, Recurso de Agravo de Instrumento 005961676.2016.4.01.0000, Relator Des. Federal Kassio Nunes Marques, 09/10/2017).
} 
Revista Eletrônica de Direito Processual - REDP.

Rio de Janeiro. Ano 13. Volume 20. Número 1. Janeiro a Abril de 2019

Periódico Quadrimestral da Pós-Graduação Stricto Sensu em Direito Processual da UERJ

Patrono: José Carlos Barbosa Moreira (in mem.). ISSN 1982-7636. pp. 250-287

www.redp.uerj.br

alteração de procedimentos dentro do sistema penal e carcerário, exigência de contratação de policiais em estados em que o quantitativo de agentes de segurança é considerado baixo ${ }^{44}$.

O STF, em sede de Recurso Extraordinário (RE 592581), com repercussão geral, fixou entendimento no sentido da possibilidade de o Poder Judiciário determinar à administração pública a realização de obras ou reformas emergenciais em presídios para garantir os direitos fundamentais dos presos, como sua integridade física e moral ${ }^{45}$.

A tese de repercussão geral que restou aprovada naquele recurso foi a de que:

É lícito ao Judiciário impor à Administração Pública obrigação de fazer, consistente na promoção de medidas ou na execução de obras emergenciais em estabelecimentos prisionais para dar efetividade ao postulado da dignidade da pessoa humana e assegurar aos detentos o respeito à sua integridade física e moral, nos termos do que preceitua o art. $5^{\circ}$, XLIX, da Constituição Federal, não sendo oponível à decisão o argumento da reserva do possível nem o princípio da separação dos poderes ${ }^{46}$.

O entendimento encampado pelo STF tem grande relevância e representa uma importante medida na busca da proteção dos direitos humanos no Brasil, sobretudo diante das condições muitas vezes indignas de muitos estabelecimentos prisionais, do grande número de presos - superior a 650 mil pessoas ${ }^{47}$, de acordo com dados de 2017 divulgados pelo $\mathrm{CNJ}$ - e os graves problemas à saúde e segurança a que estão sujeitos durante o encarceramento.

De outro lado, não se pode deixar de antecipar alguns possíveis problemas passiveis de ocorrerem, a partir do reconhecimento, por parte do STF, daquela legitimidade de atuação em favor do judiciário, diante da deficiência do sistema processual de tutela coletiva de direitos, diante da ausência de um rito processual especial voltado à intervenção do judiciário sobre as políticas públicas.

\footnotetext{
${ }^{44}$ Vide Ação Civil Pública de no 391743.19.2012.8.09.0051, movida pelo Ministério Público do estado de Goiás,

${ }^{45}$ STF, RE 592581, Relator(a): Min. RICARDO LEWANDOWSKI, Tribunal Pleno, julgado em 13/08/2015, ACÓRDÃO ELETRÔNICO REPERCUSSÃO GERAL - MÉRITO DJe-018, PUBLIC 01-02-2016).

46 Trata-se da tese sob o número 220 do STF.

${ }^{47}$ CNJ. Levantamento dos Presos Provisórios do País e Plano de Ação dos Tribunais. Disponível em: $<$ http://www.cnj.jus.br/noticias/cnj/84371-levantamento-dos-presos-provisorios-do-pais-e-plano-de-acaodos-tribunais>. Acessado em: 28 mar. 2018.
} 
Revista Eletrônica de Direito Processual - REDP.

Rio de Janeiro. Ano 13. Volume 20. Número 1. Janeiro a Abril de 2019

Periódico Quadrimestral da Pós-Graduação Stricto Sensu em Direito Processual da UERJ

Patrono: José Carlos Barbosa Moreira (in mem.). ISSN 1982-7636. pp. 250-287

www.redp.uerj.br

Imagine-se, p. ex., que o judiciário, em determinada ação coletiva, determinasse a reforma de um estabelecimento prisional para melhor acomodar os reclusos, enquanto, em outra ação, perante outro juízo, fosse reconhecida a imprestabilidade daquela instituição prisional e, consequentemente, fosse determinada à administração pública a construção de novo estabelecimento, bem como a transferência dos cidadãos presos para novos locais.

Fica evidenciado que a intervenção do judiciário no exemplo hipotético poderia ser considerada inadequada e prejudicial ao alcance de uma máxima eficiência no atendimento da política pública carcerária. Embora as decisões conflitantes no exemplo acima fossem, num segundo momento, passíveis de adequação a partir de sua análise em conjunto, não se pode desconsiderar a existência de eventuais prejuízos permanentes decorrentes da atuação pulverizada do judiciário - como, p. ex., decorrente de concessão de liminares etc.

\section{d) Políticas relativas à saúde}

A saúde também é considerada um direito fundamental social (art. $6^{\circ}$ ) e a ela a Constituição da República reserva vários dispositivos destinados a fixar os deveres do poder público e direitos da sociedade.

Diante do acesso universal à saúde a toda a sociedade e da amplitude da cobertura garantidos pela Constituição e da evolução da medicina nas últimas décadas, provavelmente essa é a seara em que o judiciário mais tem sido chamado a agir e em que a intervenção judicial sobre as políticas públicas se faz mais presente.

Somente a título ilustrativo, de acordo com dados do Ministério da Saúde, verifica-se um gasto crescente com a judicialização da saúde nos últimos anos. Passou-se, segundo aquele Ministério, de um consumo de cerca de R\$ 122,6 milhões em 2010 para R \$ 1,313 bilhão em 2016 do gasto público federal destinado a pagamento de medicamentos deferidos judicialmente. Tais números representam um aumento de mais de $1.000 \%$ do valor gasto em sete $\operatorname{anos}^{48}$.

A incompatibilização dos limitados recursos orçamentários destinados aos investimentos em saúde pública e a crescente demanda pela via judicial de atendimentos

48 CNJ. Ministério da Saúde alerta sobre custos da judicialização. Disponível em: http://www.cnj.jus.br/noticias/cnj/85915-ministerio-da-saude-alerta-sobre-custos-da-judicializacao. Acessado em: 21 mar. 2018. 
Revista Eletrônica de Direito Processual - REDP.

Rio de Janeiro. Ano 13. Volume 20. Número 1. Janeiro a Abril de 2019

Periódico Quadrimestral da Pós-Graduação Stricto Sensu em Direito Processual da UERJ

Patrono: José Carlos Barbosa Moreira (in mem.). ISSN 1982-7636. pp. 250-287

www.redp.uerj.br

casuísticos, muitas vezes desconectados da macropolítica do sistema público, traz graves consequências para a totalidade da população.

De outro lado, casos flagrantes de morosidade e má utilização de verba pública pela administração pública confrontada com casos patentes de negativa de acesso à garantia do direito à saúde fazem com que o judiciário seja visto, em muitos casos, como a única ou última via de salvaguarda dos direitos fundamentais da população.

Diante da proliferação de ações judiciais individuais e coletivas buscando a expansão das políticas públicas na área da saúde, importantes iniciativas têm sido adotadas pela cúpula do judiciário, na tentativa de criação de maiores regramentos à atuação dos juízes. Em relação à concessão judicial de medicamentos não fornecidos pelo Sistema Único de Saúde, o Superior Tribunal de Justiça, recentemente, diante da constatação de uma multiplicidade de ações judiciais em que se controvertia sobre a mesma questão jurídica, decidiu por afetar para julgamento, nos termos do que determina os arts. 1036 e seguintes do CPC, ao julgamento de Recurso Especial Repetitivo, a fim de julgar a seguinte questão controvertida: "Obrigação do Poder Público de fornecer medicamentos não incorporados, através de atos normativos, ao Sistema Único de Saúde"49.

Determinou o STJ, no referido incidente, em obediência à legislação processual (art. 1.037, II, do CPC) a suspensão, em todo o território nacional, dos processos pendentes, individuais e coletivos, que versem sobre aquela questão afetada, até final definição sobre o $\operatorname{assunto}^{50}$.

Em Acórdão publicado em 04/05/2018, a Primeira Seção do STJ firmou, sobre o assunto, o Tema 106, com a seguinte redação:

A concessão dos medicamentos não incorporados em atos normativos do SUS exige a presença cumulativa dos seguintes requisitos:

i) Comprovação, por meio de laudo médico fundamentado e circunstanciado expedido por médico que assiste o paciente, da imprescindibilidade ou necessidade do medicamento, assim como da ineficácia, para o tratamento da moléstia, dos fármacos fornecidos

\footnotetext{
${ }^{49}$ STJ, QO na ProAfR no REsp 1657156/RJ, Rel. Ministro BENEDITO GONÇALVES, PRIMEIRA SEÇÃO, julgado em 24/05/2017, DJe 31/05/2017)

${ }^{50}$ Até o presente momento o recurso afetado não foi julgado no âmbito do STJ.
} 
Revista Eletrônica de Direito Processual - REDP.

Rio de Janeiro. Ano 13. Volume 20. Número 1. Janeiro a Abril de 2019

Periódico Quadrimestral da Pós-Graduação Stricto Sensu em Direito Processual da UERJ

Patrono: José Carlos Barbosa Moreira (in mem.). ISSN 1982-7636. pp. 250-287

www.redp.uerj.br

pelo

SUS;

ii) incapacidade financeira de arcar com o custo do medicamento prescrito;

iii) existência de registro do medicamento na ANVISA, observados os usos autorizados pela agência.

\section{ASPECTOS DO ATUAL SISTEMA PROCESSUAL DE INTERVENÇÃO} JUDICIAL SOBRE AS POLÍTICAS PÚBLICAS QUE MERECEM ADEQUAÇÃO

Não se pode deixar de reconhecer que, nas últimas décadas, verificou-se uma significativa transformação do sistema processual, a fim de melhor abarcar as demandas dos direitos fundamentais, sobretudo com a criação de instrumentos que favorecem a tutela coletiva de direitos $^{51}$, e superar o sistema até então vigente e que privilegiava a litigância tradicional, baseada no litígio particular, geralmente envolvendo um autor e um réu, na defesa de interesses individuais ${ }^{52}$.

Nesse sentido, afirma Teori Zavascki:

[...] as diversas modificações legislativas supervenientes, ocorridas principalmente a partir de 1985, alteraram de modo substancial não apenas o Código de Processo, mas o próprio sistema processual nele consagrado. Novos instrumentos processuais foram criados e importantes reformas foram aprovadas, a tal ponto que, do exame sistemático do conjunto da legislação processual, impõe-se, hoje, concluir que o processo civil já não se limita à prestação da tutela jurisdicional nas modalidades clássicas ao início referidas e nem se restringe a solucionar conflitos de interesses individualizados e concretizados ${ }^{53}$.

No período apontado pelo autor surge como importante marco da tutela coletiva de direitos no Brasil as várias leis que regulamentaram as chamadas 'ações civis públicas', a

\footnotetext{
${ }^{51}$ BUCCI, op. cit., p. 145.

52 ZAVASCKI, Teori Albino. Processo coletivo: tutela de direitos coletivos e tutela coletiva de direitos. São Paulo: Editora Revista dos Tribunais, 2006, p. 17-18. Cf., ainda, Calmon de Passos, op. cit., p. 90, para quem: "O alargamento que se deu à atividade do Estado não importou em alteração substancial da função de julgar, voltada ainda e exclusivamente para a solução dos micro-conflitos, apenas enriquecido este universo com os novos conflitos entre os sujeitos de direito em geral e os agentes público, também estes limitados, agora, pela lei, por conseguinte suscetíveis de serem questionados perante os órgãos da função jurisdicional". ${ }^{53}$ ZAVASCKI, op. cit., p. 18.
} 
Revista Eletrônica de Direito Processual - REDP.

Rio de Janeiro. Ano 13. Volume 20. Número 1. Janeiro a Abril de 2019

Periódico Quadrimestral da Pós-Graduação Stricto Sensu em Direito Processual da UERJ

Patrono: José Carlos Barbosa Moreira (in mem.). ISSN 1982-7636. pp. 250-287

www.redp.uerj.br

partir da Lei 7.347, aprovada em 24 de julho de $1985^{54}$. Nesse período, na tutela daqueles interesses transindividuais, a consolidação do instituto processual da substituição processual permitiu que representantes da coletividade ingressassem em juízo na defesa daqueles interesses coletivos $^{55}$. Tal instituto foi, posteriormente, reconhecido como direito fundamental pela atual Constituição da República a legitimação de entes representativos de coletividades (associações e sindicatos), bem como a expansão das atribuições do Ministério Público na defesa daqueles interesses coletivos ${ }^{56}$.

Mais recentemente, a partir da Emenda Constitucional 80, de 2014, foi estendida à Defensoria Pública, de forma explicita, a prerrogativa de defesa dos direitos coletivos da população mais carente (art. 134 da Constituição da República).

Atualmente, as possibilidades de intervenção do judiciário sobre as políticas públicas são várias, tanto no âmbito do controle concentrado, no âmbito do no $\mathrm{STF}^{57}$, como na via difusa, entre os milhares de juízos espalhados pelo país.

Digno de nota o fato de que, mais recentemente, a partir de relativamente recentes reformas constitucionais, a partir da Emenda Constitucional 45, de 2004, foram criados importantes instrumentos que permitem que decisões proferidas pelo STF em controle difuso criem efeitos vinculantes em relação aos demais órgãos do judiciário e à administração pública.

Inegável a importância de possibilidade de maior controle da população sobre as políticas públicas, por intermédio do judiciário. Mas, por outro lado, há problemas a serem apontados e a se buscar superar. E expor alguns desses problemas e possíveis soluções sob o ponto de vista processual é o objetivo maior do presente texto. ${ }^{58}$

Nesse sentido, no presente momento serão apresentados alguns aspectos que evidenciam problemas persistentes em relação ao controle judicial sobre as políticas

\footnotetext{
${ }^{54}$ Ibidem, p. 19. De acordo, ainda, com Zavascki, tal sistema de tutela coletiva teria se inspirado nas ações de classe (class action), do sistema norte-americano, mas apresentaria vários avanços em relação àquele modelo (ZAVASCKI, p. 30).

55 Ibidem, p. 19.

${ }^{56}$ Ibidem, p. 20.

${ }^{57}$ BARBOZA \& KOZICKI, op. cit., p. 75.

${ }^{58}$ ARENHART, Sergio Cruz. As ações coletivas e o controle das políticas públicas pelo Poder Judiciário. In: Revista Eletrônica do Ministério Público Federal, I. Disponível em: http://www.prrj.mpf.mp.br/custoslegis. Acessado em: 02 mar. 2018, p. 1: "A ampliação no uso das demandas coletivas para a proteção de interesses frente ao Poder Público torna-se, então, mecanismo de participação da sociedade na administração da coisa pública. Nesse passo, as demandas coletivas acabam assumindo o papel de verdadeiro instrumento de democracia participativa, servindo para extravasar as diversas orientações populares sobre os rumos a serem adotados pelo governo nacional".
} 
Revista Eletrônica de Direito Processual - REDP.

Rio de Janeiro. Ano 13. Volume 20. Número 1. Janeiro a Abril de 2019

Periódico Quadrimestral da Pós-Graduação Stricto Sensu em Direito Processual da UERJ

Patrono: José Carlos Barbosa Moreira (in mem.). ISSN 1982-7636. pp. 250-287

www.redp.uerj.br

públicas, a fim de se buscar apontar algumas soluções, sobretudo de caráter legislativo -, a

fim de garantir caminhos mais seguros para a atuação do judiciário e evitar, dentre outros problemas, nas palavras de Fabio Konder Comparato "o caos na Administração Pública e nos negócios privados",59.

Esclareça-se, aqui, que o presente trabalho, de caráter crítico-propositivo, pauta-se, sobretudo, na busca de soluções processuais de caráter coletivistas - portanto, não casuísticas, individuais - para as políticas públicas, a partir das limitações e insuficiências do instrumental processual atualmente existentes ${ }^{60}$.

Assim, foge ao interesse do texto a busca de soluções restritas aos litígios no formato tradicional, que tencionam, de forma individualizada, a atuação do judiciário no sentido de garantir direitos fundamentais perante o Estado. Pelo contrário, as proposições a serem apontadas passam, necessariamente, como exposto adiante, pela busca de uma conformação entre as demandas individuais e a ação coletiva que buscam a atuação do judiciário na garantia de efetivação de políticas públicas.

Da mesma forma, escapa do âmbito de discussão nos tópicos seguintes discutir as ações que buscam o controle concentrado de constitucionalidade e legalidade (ADI, ADC, $\mathrm{ADPF}$ ), que já possuem um sistema processual específico e bem consolidado previstos na Constituição da República e legislação ordinária ${ }^{61}$.

\subsection{Necessidade de se buscar uma tutela adequada aos processos judiciais em} que se busca a intervenção e controle sobre políticas públicas

A busca da tutela judicial para a implementação de políticas públicas nem sempre encontra no sistema jurídico processual em vigor o ambiente adequado para uma efetiva

\footnotetext{
${ }^{59}$ COMPARATO, p. 47. Cf., também, GRINOVER, op. cit., p. 25: “O Direito propõe-se a ensejar uma certa estabilidade, um mínimo de certeza na regência da vida social. Daí o chamado princípio da segurança jurídica, o qual, bem por isto, é, indiscutivelmente, um de seus princípios mais importantes".

${ }^{60}$ Acerca das limitações do sistema de tutela coletiva de direitos no sistema processual brasileiro, afirma Ada Pellegrini Grinover, op. cit., p. 56: "Muitos são os méritos do processo coletivo brasileiro, mas ainda há dificuldades em sua aplicação".

61 A Lei 9.868 , de 10 de novembro de 1999, dispõe sobre o processo e julgamento da Ação Direta de Inconstitucionalidade e da Ação Declaratória de Constitucionalidade perante o Supremo Tribunal Federal e a Lei 9.882, de 3 de dezembro de 1999, dispõe sobre o processo e julgamento da Argüição de Descumprimento de Preceito Fundamental, nos termos do $§ 1^{\circ}$ do art. 102 da Constituição Federal.
} 
Revista Eletrônica de Direito Processual - REDP.

Rio de Janeiro. Ano 13. Volume 20. Número 1. Janeiro a Abril de 2019

Periódico Quadrimestral da Pós-Graduação Stricto Sensu em Direito Processual da UERJ

Patrono: José Carlos Barbosa Moreira (in mem.). ISSN 1982-7636. pp. 250-287

www.redp.uerj.br

resolução ${ }^{62}$. De acordo com Ada Pellegrini Grinover, essa tutela efetiva deverá ser "justa, efetiva e adequada" ${ }^{\prime \prime}$.

A referida autora muito bem percebeu as peculiaridades da tutela jurisdicional de interesses coletivos na busca da implementação de políticas públicas. Segundo a autora:

E o que importa para a processualidade é que os direitos metaindividuais são tutelados por processos coletivos; mas os direitos públicos são tutelados por uma espécie típica de processo coletivo, que é denominado processo de interesse público ou processo estrutural. E o procedimento do processo coletivo, que chamaremos genérico, é diferente daquele do processo coletivo estrutural, porque o primeiro deve ser adequado à solução de um conflito coletivo limitado a uma comunidade, enquanto o segundo deve ser adequado a obter a fruição de direitos sociais (ou prestacionais) assegurados a toda a população e que dependem de políticas públicas $^{64}$.

A prática da atuação jurisdicional em ações envolvendo políticas públicas tem demonstrado, justamente, que a intervenção judicial, dentro do existente sistema de tutela coletiva "genérico", traz alguns problemas que aquela onda de reformas ocorridas nas décadas anteriores não pôde contemplar, sobretudo porque, àquele momento, o grau de intervenção do judiciário sobre as políticas públicas era consideravelmente menor do que o hoje constatado.

\subsection{Problemas relativos à competência jurisdicional}

O tema referente à competência ainda representa grande desafio dentro do sistema jurisdicional brasileiro ${ }^{65}$. Não se dá de modo diverso quando se trata de tutela jurisdicional coletiva sobre políticas púbicas. Em situações como aquelas dos exemplos práticos anteriormente apresentados, verifica-se, em tese, a probabilidade de existência de demandas idênticas ou similares, com o potencial de impactar a mesma seara de política pública.

\footnotetext{
${ }^{62}$ GRINOVER, op. cit., p. 34.

${ }^{63}$ Ibid., p. 34.

${ }^{64}$ Ibid., p. 42.

${ }^{65}$ Ibid., p. 56: "Assim, por exemplo, dúvidas e problemas surgem sobre a natureza da competência territorial (absoluta ou relativa).
} 
Revista Eletrônica de Direito Processual - REDP.

Rio de Janeiro. Ano 13. Volume 20. Número 1. Janeiro a Abril de 2019

Periódico Quadrimestral da Pós-Graduação Stricto Sensu em Direito Processual da UERJ

Patrono: José Carlos Barbosa Moreira (in mem.). ISSN 1982-7636. pp. 250-287

www.redp.uerj.br

O exemplo apontado sobre as ações envolvendo o exame do ENEM dão uma boa mostra do problema. Trata-se de um exame de grande repercussão nacional e, por vezes, seria possível a coexistência de decisões contraditórias entre juízes espalhados por todo o país, sobretudo em caráter de tutela de urgência, que poderiam trazer graves prejuízos para a coletividade, como a suspensão dos exames.

Lembre-se que, em tese, que nos casos de ações coletivas em que se busca reparar danos de alcance regional ou nacional, com base na legislação processual em vigor, competente para processar e julgar a demanda seria qualquer juízo do foro da Capital do Estado ou do Distrito Federal, nos termos do que dispõe o art. 93 da Lei 8.078/90 ${ }^{66}$.

Dessa forma, diante de política pública federal, ter-se-ia a real possibilidade de juízes de todas a capitais de estados e do Distrito Federal apreciarem, simultaneamente, ações sobre a mesma temática ou questão conexa. Em casos como tais, a resolução de conflitos de competência passiveis de serem instaurados demandaria a interferência dos tribunais locais - caso os juízes estivessem vinculados ao mesmo tribunal - ou até mesmo perante o STJ, em caso de juízes vinculados a tribunais diversos. ${ }^{67}$

A redução dos foros competentes poderia significar uma drástica limitação dos potenciais conflitos de competência nessa seara e concorreria para a implementação de uma maior unicidade de posicionamento do judiciário. Ademais, a concentração da competência em quantidade menor de órgãos jurisdicionais teria por consequência a possibilidade de maior especialização sobre as matérias dos juízes residualmente competentes. Em consequência, ter-se-ia como consequência lógica a criação de uma maior credibilidade da função jurisdicional ${ }^{68}$.

\footnotetext{
${ }^{66} \mathrm{O}$ STJ possui jurisprudência consolida no sentido de reconhecer, em relação à matéria de competência para apreciação de ações coletivas, a existência de integração normativa entre o art. 93 do CDC e da Lei da Ação Civil Pública. Nesse sentido, vide STJ, AgInt no REsp 1528392/SP, Rel. Ministro HERMAN BENJAMIN, SEGUNDA TURMA, julgado em 20/04/2017, DJe 05/05/2017.

${ }^{67}$ Dispõe o art. 105, I, d, da Constituição da República: "Art. 105. Compete ao Superior Tribunal de Justiça: I - processar e julgar, originariamente: [...] d) os conflitos de competência entre quaisquer tribunais, ressalvado o disposto no art. 102, I, "o", bem como entre tribunal e juízes a ele não vinculados e entre juízes vinculados a tribunais diversos; [...]". O STJ decidiu, em sede de conflito de Competência negativo entre juízes das Varas Federais de Curitiba/PR e Campo Grande/MS, pela competência deste último em caso de Ação Civil Pública movida pelo MPF e que buscava a nomeação de candidatos aprovados em concurso público federal em concorrência a reserva de vagas para pessoas portadoras de deficiência. Vide: STJ, CC 109.435/PR, Rel. Ministro NAPOLEÃO NUNES MAIA FILHO, TERCEIRA SEÇÃO, julgado em 22/09/2010, DJe 15/12/2010).

${ }^{68}$ GRINOVER, op. cit., p. 149: "Não é possível, e atenta contra a credibilidade do Poder Judiciário, que duas causas idênticas, com as mesmas questões de fato e de direito, sejam julgadas de forma diferente".
} 


\subsection{A inviabilidade de distribuição de soluções individualizadas pelo judiciário para problemas que atingem a coletividade}

É comum, também, o ajuizamento de demandas individuais e coletivas perante juízos no interior do país, de alcance limitado e que, em sua soma, podem comprometer toda política pública daquela seara.

No âmbito da educação, verifica-se, apenas a título exemplificativo, um grande número de ações civis públicas que têm buscado o fornecimento de profissionais habilitados em linguagem de sinais nos campi ou instituições de ensino federais quando o poder público não teria disponibilizado tais profissionais onde se constata a sua necessidade ou sua disponibilização se apresentaria em quantidades entendidas como insuficientes pelos demandantes.

$\mathrm{Na}$ esfera administrativa, ao buscar solucionar a demanda de deficiência de profissionais habilitados em atividade no seu sistema de ensino, o poder público federal permitiu a contratação, recentemente, de um quantitativo - não interessa aos fins do presente estudo discutir se tal quantitativo é elevado ou reduzido - de profissionais habilitados na área para buscar equacionar o problema em nível global ${ }^{69}$.

Assim, qualquer ação judicial coletiva julgada procedente em determinada localidade contra os Institutos Federais de Educação e o MEC e que viesse a determinar a contratação daqueles profissionais para determinado instituto ou campi traria impacto negativo para os demais entes de educação. Mais do que isso, criar-se-ia, na prática, a distinção de duas classes de grupos sociais, em que o primeiro se caracterizaria como um grupo beneficiário da intervenção judiciária e outro recebedor dos efeitos danosos da solução judicial, sem que ao menos fosse parte do processo coletivo julgado procedente em favor daquele primeiro grupo.

Mais do que isso, diante da possibilidade de coexistência dessas ações, individuais e coletivas, que, reunidas, trazem relevante impacto no planejamento e implementação da

\footnotetext{
${ }^{69}$ No ano de 2017, por meio da Portaria Interministerial $n^{\circ} 102$, firmada entre os Ministros do Planejamento, Desenvolvimento e Gestão e da Educação, foi autorizada a contratação por tempo determinado, de "cento e cinquenta profissionais técnicos especializados em linguagem de sinais, de nível superior, no âmbito do Ministério da Educação - MEC, para atender demandas dos Institutos Federais de Educação, Ciência e Tecnologia, dos Centros Federais de Educação Tecnológica Celso Suckow da Fonseca - CEFET-RJ e de Minas Gerais - CEFET-MG e do Colégio Pedro II"'
} 
Revista Eletrônica de Direito Processual - REDP.

Rio de Janeiro. Ano 13. Volume 20. Número 1. Janeiro a Abril de 2019

Periódico Quadrimestral da Pós-Graduação Stricto Sensu em Direito Processual da UERJ

Patrono: José Carlos Barbosa Moreira (in mem.). ISSN 1982-7636. pp. 250-287

www.redp.uerj.br

política pública global pela administração, a ausência de controle efetivo sobre a viabilidade das decisões no contexto global da atuação da administração poderia representar graves prejuízos à sua implementação ${ }^{70}$.

A solução judicial nos termos acima criticados, pensada de forma individualizada e descolada de maiores preocupações sobre a globalidade da política pública, traria outro prejuízo para a política pública em momento posterior. A tradicional lógica da criação de uma "imutabilidade" à sentença após o decurso dos prazos recursais (trânsito em julgado) criaria dificuldades para a readequação da solução no futuro, mesmo diante de uma alteração da realidade fática. No caso do exemplo citado, imagine-se que deixasse de existir demanda por profissionais habilitados em LIBRAS em localidade contemplada com tutela coletiva em seu favor, enquanto em outra unidade educacional (não contemplada) fosse constatado o surgimento de uma demanda anteriormente inexistente.

Claramente, no caso do exemplo acima apontado, seria desejável que eventual intervenção judicial sobre política pública relativa a disponibilização de profissionais especializados em LIBRAS fosse debatida de forma global, de preferência em uma única ação judicial, a fim de se evitar que soluções casuísticas trouxesse resultados negativos para o conjunto daquela política pública. Além disso, tal política deveria poder adequar a disponibilização daqueles profissionais especializados de acordo com eventuais alterações de sua necessidade em cada unidade de ensino.

\subsection{Ausência de um rito específico para ações coletivas que tenham por}

\section{objetivo a implementação de políticas públicas}

Como já referido acima, em que pese o surgimento de importantes institutos que favoreceram uma melhor efetividade na tutela de direitos coletivos, a legislação processual pátria não contemplou um rito processual específico para as demandas que busquem a implementação de políticas públicas.

A Lei da Ação Civil Pública prevê, de forma expressa, a aplicação subsidiária do Código de Processo Civil, quando aquele diploma restar omisso. Por outro lado, observa-se a existência de uma clara omissão em relação às peculiaridades que a intervenção judicial

\footnotetext{
${ }^{70}$ Cite-se, aqui, como exemplo, a Ação Civil Pública no 5001968-85.2016.4.04.7011/PR, ajuizada perante o juízo federal de Paranavai/PR pelo MPF contra o Instituto Federal do Paraná em agosto de 2016 e que busca seja o réu compelido a disponibilizar a cada aluno com deficiência auditiva, em todas as aulas e atividades complementares, um tradutor/intérprete de língua brasileira de sinais (LIBRAS).
} 
Revista Eletrônica de Direito Processual - REDP.

Rio de Janeiro. Ano 13. Volume 20. Número 1. Janeiro a Abril de 2019

Periódico Quadrimestral da Pós-Graduação Stricto Sensu em Direito Processual da UERJ

Patrono: José Carlos Barbosa Moreira (in mem.). ISSN 1982-7636. pp. 250-287

www.redp.uerj.br

sobre políticas públicas impõe. Assim, em resumo, tem-se que o principal instrumento processual que apresenta o rito das ações civis públicas é aquele código eivado de preocupações relacionadas aos conflitos individuais.

Dá-se margem, dessa forma, nas ações coletivas que buscam o controle jurisdicional de políticas públicas, diante da vagueza da legislação em vigor, a uma atuação inadequada por parte do judiciário e demais atores processuais. Assim, o caminho natural nas demandas dessa natureza, após o ajuizamento da ação e apresentação de defesa por parte do ente público demandado, consiste na apresentação de provas e, apresentadas as alegações das partes, solução normal não resta ao julgador que não seja a apresentação de sentença.

Não se prevê, no vigente sistema de tutela coletiva de direitos, um período preliminar em que o ente público possa apresentar uma explanação das políticas públicas adotadas na seara impugnada, o planejamento dos investimentos existentes, o impacto que a demanda judicial traria para aquela área.

A legislação processual atualmente aplicável, salvo nos casos de prevenção, não permite a reunião de processos que, ajuizados perante juízos diversos, possam, individualmente, comprometer a implementação de uma forma global as políticas públicas de determinado setor.

Não é prevista, da mesma forma, de modo expressa, a obrigatoriedade de audiências públicas em que se possa ouvir interessados, especialistas na área da política pública em questão.

Ademais, a lógica do conflito, do litígio, prevalece no atual rito das ações coletivas hoje vigente. Tal formato de processo, em muitos casos, não condiz com a melhor solução para demandas envolvendo a implementação de políticas públicas. Pelo contrário, em diversas ocasiões caberia ao judiciário funcionar como uma arena em que fosse possível um diálogo entre administração pública e sociedade, em que aquela pudesse expor as medidas concretas existentes para contemplar as políticas públicas buscadas, suas limitações, e a sociedade apontar sua urgência e propor alternativas ${ }^{71}$.

\footnotetext{
${ }^{71}$ BUCCI, op. cit., p. 150: "Esse é o sentido político-institucional do controle judicial de políticas públicas num cenário democrático. Não se trata de conceber o Poder Judiciário como mera arena de conflitos, mas respeitar que a exigência judicial de direitos seja uma alternativa possível. Diante dela, cabe à autoridade prestar contas, informar como está sendo planejado o enfrentamento da questão, quais os meios imediatamente disponíveis, quais os resultados a serem obtidos ao longo do tempo. Só desse modo se terá o verdadeiro escrutínio da conduta do Poder Público, sem parti pris, seja de um lado, seja de outro".
} 
Revista Eletrônica de Direito Processual - REDP.

Rio de Janeiro. Ano 13. Volume 20. Número 1. Janeiro a Abril de 2019

Periódico Quadrimestral da Pós-Graduação Stricto Sensu em Direito Processual da UERJ

Patrono: José Carlos Barbosa Moreira (in mem.). ISSN 1982-7636. pp. 250-287

www.redp.uerj.br

No sentido da constatação do problema ora apontado e da necessidade de sua superação por meio de um novo sistema processual de controle das políticas públicas é o entendimento de Ada Pellegrini Grinover, para quem:

[...] para que o controle jurisdicional de políticas públicas se faça de maneira justa, equilibrada e exequível, é necessário instituir um novo processo, que é justamente o processo adequado à solução dos conflitos de interesse público: o processo chamado estrutural ${ }^{72}$.

A existência de um rito adequado tem por finalidade, também, uma garantia dos interessados contra atuações arbitrárias do julgador e de atuações protelatórias da fazenda pública em juízo. Nesse sentido, afirma Calmon de Passos:

Devido processo constitucional jurisdicional, cumpre esclarecer, para evitar sofismas e distorções maliciosas, não é sinônimo de formalismo, nem culto da forma, do rito pelo rito, sim um complexo de garantias mínimas contra o subjetivismo e arbítrio dos que têm poder de decidir ${ }^{73}$.

\subsection{A duração excessiva dos processos judiciais}

Das diversas análises possíveis sobre os números trazidos pelos relatórios estatísticos do CNJ sobre movimentação judicial uma tem especial importância no desenvolvimento deste trabalho e consiste em refletir sobre os limites de resposta pelo judiciário brasileiro à crescente demanda da sociedade pela prestação jurisdicional, especialmente no período posterior à promulgação da Constituição da República de 1988, que ampliou o rol de direitos e garantias do cidadão ${ }^{74}$.

Os relatórios referidos permitem constatar as limitações da capacidade do judiciário em responder em um tempo adequado às demandas da sociedade, seja por limitações

\footnotetext{
72 GRINOVER, op. cit., p. 50.

${ }^{73}$ PASSOS, op. cit., p. 69. Segundo, ainda, Calmon de Passos, op. cit., p. 70: "Dispensar ou restringir qualquer dessas garantias não é simplificar, deformalizar, agilizar o procedimento privilegiando a efetividade da tutela, sim favorecer o arbítrio em benefício do desafogo de juízos e tribunais. Favorece-se o poder, não os cidadãos, dilata-se o espaço dos governantes e restringe-se o dos governados. E isso se me afigura a mais escancarada anti-democracia que se pode imaginar".

${ }^{74}$ CNJ. Justiça em Números 2017: ano-base 2016.
} 
Revista Eletrônica de Direito Processual - REDP.

Rio de Janeiro. Ano 13. Volume 20. Número 1. Janeiro a Abril de 2019

Periódico Quadrimestral da Pós-Graduação Stricto Sensu em Direito Processual da UERJ

Patrono: José Carlos Barbosa Moreira (in mem.). ISSN 1982-7636. pp. 250-287

www.redp.uerj.br

orçamentárias, seja pela persistência de um sistema - e de uma cultura - que privilegia a litigiosidade e o formalismo processual, em prejuízo da celeridade ${ }^{75}$.

Diante deste cenário preocupante, têm-se desenvolvido algumas estratégias para uma maior racionalização do quantitativo de processos judiciais surgidos, bem como para fomentar uma maior agilidade naqueles existentes ${ }^{76}$.

A constitucionalização do direito fundamental a uma razoável duração do processo judicial responde, em grande medida, aos anseios da sociedade e também a documentos de direito internacional já aprovados pelo Brasil. É o caso da Convenção Americana de Direitos Humanos ${ }^{77}$ - Pacto de San Jose da Costa Rica -, que nos arts. $7^{\circ}$ e $8^{\circ}$ prevê como dever dos Estados-partes a garantia ao cidadão, sobretudo em casos de restrições à liberdade, de serem julgados dentro de um prazo razoável.

Sabe-se que a criação de normas, ainda que constitucionais, não é o bastante para garantir o fim da insuficiência da prestação de uma ação estatal, como é a jurisdicional, sobretudo quando a alteração da realidade fática envolve investimentos públicos e mudanças no sistema procedimental então vigente. No entanto, alguns impactos do novo comando normativo são perceptíveis, principalmente no que diz respeito ao aumento do controle, pelo Conselho Nacional de Justiça, pelos tribunais e suas corregedorias, sobre os prazos de duração dos processos.

Não obstante o importante passo representado pelas mudanças acima expostas, não se pode negar o elevado número de processos em tramite no Brasil e a tendência de que tal quantidade seja incrementada a cada ano, de modo a tornar impraticável a extensão do direito a uma razoável duração do processo a todos ou a uma importante parte dos litigantes.

Desse modo, outras alternativas se fazem necessárias, seja para reduzir a duração dos processos em trâmite, seja para evitar o ajuizamento de ações evitáveis ${ }^{78}$.

75 CNJ. Justiça em Números 2017: ano-base 2016. Brasília: CNJ, 2017. Disponível em: <http://www.cnj.jus.br>. De acordo com o referido relatório, têm-se constatado um gradual aumento no número de processos pendentes de solução, passando de cerca de 60,7 milhões em 2009 para mais de 79 milhões de processos em 2016.

${ }^{76}$ A LC 101/2000, em seus arts. 19 e 20, prevê que o limite de gasto do judiciário federal com pessoal não poderá ultrapassar a $6 \%$ da receita corrente líquida. Segundo dados do Tesouro Nacional, no ano de 2009 tal rubrica atingiu de cerca de $\mathrm{R} \$ 476,469$ bilhões. O limite de gasto do judiciário federal seria, assim, de cerca de $\mathrm{R} \$ 28,5$ bilhões. Contudo, naquele ano, o gasto efetivado pelo judiciário federal atingiu cerca de $\mathrm{R} \$ 26,464$ bilhões. Fica claro, dessa forma, a limitação existente para se aumentar em quantidade considerável juízes e servidores no âmbito desta função estatal.

${ }^{77}$ Referida convenção restou promulgada pelo Decreto Presidencial 678/1992.

${ }^{78}$ MARINONI, Luiz Guilherme \& ARENHART, Sergio Cruz. Manual do processo de conhecimento. 5. ed. rev., atual. e ampl. São Paulo: Revista dos Tribunais, 2006. Os autores corroboram aquela constatação, ao 
Revista Eletrônica de Direito Processual - REDP.

Rio de Janeiro. Ano 13. Volume 20. Número 1. Janeiro a Abril de 2019

Periódico Quadrimestral da Pós-Graduação Stricto Sensu em Direito Processual da UERJ

Patrono: José Carlos Barbosa Moreira (in mem.). ISSN 1982-7636. pp. 250-287

www.redp.uerj.br

No que pertine ao controle jurisdicional sobre políticas públicas, em especial aquelas

que buscam a tutela coletiva dos interesses da sociedade, essa realidade se mostra mais evidente. Por mais esse motivo, a busca de soluções que permitam solucionar esses processos pela via conciliativa ou a partir de uma interação entre relevantes setores da sociedade interessados e do poder público, são princípios maiores que devem reger a construção de um novo processo coletivo de controle de políticas públicas ${ }^{79}$.

\subsection{Atuação excessiva e descoordenada do Ministério Público}

Maria Paula Dallari Bucci aponta para a necessidade de aprimoramento da atuação do Ministério Público na defesa de políticas públicas, ante a relativa modéstia das vitórias, ante a expectativa criada a partir da Constituição da República de $1988^{80}$. De fato, constata-se a necessidade de uma mudança ou aprimoramento da postura institucional do Ministério Público em relação a essa temática, por alguns motivos.

Primeiramente, observa-se que tem sido comum o ajuizamento, pelo Ministério Público, de ações coletivas com alcance espacial limitado, quando seria mais eficiente o ajuizamento de apenas uma ou algumas ações, de alcance mais abrangente ${ }^{81}$.

Em casos envolvendo controle judicial de políticas públicas torna-se absolutamente necessária a concentração da atuação do Parquet ou outro legitimado para tanto. Por outro lado, a atuação dispersa e individualizada traz maiores dificuldades para uma harmonização da política pública em âmbito mais global.

afirmar que: “O Estado, apesar dos esforços dos legisladores em dotar seu processo jurisdicional de maior eficácia, tem encontrado dificuldades em solucionar, de forma rápida e efetiva, os conflitos a ele trazidos” ( $p$. $35)$.

${ }^{79}$ BUCCI, op. cit., p. 147.

${ }^{80}$ Ibid., p. 148.

${ }^{81}$ A título exemplificativo, verifica-se o ajuizamento de algumas Ações Civis Públicas pelo MPF e que busca a adequação da administração pública federal (União e ANTT), de políticas públicas de fiscalização sobre empresas concessionárias/permissionárias de serviço público de transporte interestadual quanto à forma de aquisição de passagens interestaduais com gratuidade ou para os idosos que preencham as condições exigidas pelo Estatuto do Idoso. No caso, alega o MPF a ilegalidade/inconstitucionalidade da limitação temporal de 6 e 12 horas, imposta pelo Decreto 5.934/2006 e Resolução 1.692/2006 da ANTT, para aquisição das passagens pelos idosos, nos termos mais benéficos previstos no Estatuto do Idoso. Em uma rápida pesquisa, verificam-se várias ações com o mesmo objetivo perante a justiça federal, tais como: 5050906-04.2017.4.04.7100, em Porto Alegre/RS, 5011317-05.2017.4.04.7003, em Maringá/PR; 0100049-61.2015.4.02.5002, em Cachoeiro do Itapemirim/ES, 50001390920174036124, em Jales/SP; 0006150-26.2015.4.01.4100, em Porto Velho/RO, 0049705-64.2012.4.01.3400, no DF. 
Revista Eletrônica de Direito Processual - REDP.

Rio de Janeiro. Ano 13. Volume 20. Número 1. Janeiro a Abril de 2019

Periódico Quadrimestral da Pós-Graduação Stricto Sensu em Direito Processual da UERJ

Patrono: José Carlos Barbosa Moreira (in mem.). ISSN 1982-7636. pp. 250-287

www.redp.uerj.br

De extrema relevância buscar uma maior conciliação entre os princípios institucionais

do Ministério Público, relativos a, de um lado, o da independência funcional e, de outro, o da unidade, ambos previstos na Constituição da República (art. 127).

O princípio da independência funcional tem por finalidade maior garantir a autonomia da atuação do membro do Ministério Público, de modo a tornar-lhe protegido de interferências políticas externas ${ }^{82}$. Por outro lado, como denuncia Maria Paula Dallari, a atual configuração da organização do Ministério Público tem dado margem a atuações muitas vezes eivadas de excessos de imposição de visões pessoais do promotor-autor e carentes de coordenação em nível institucional ${ }^{83}$.

Tais fatores concorrem para um baixo índice de sucessos das ações coletivas movidas pelo Ministério Público e voltadas aos controles das políticas públicas ${ }^{84}$. Desse modo, em demandas que envolvam o controle judicial de políticas públicas, de forma coletiva, o princípio da unidade deve ser sobrevalorizado. Nesse sentido, o fortalecimento de coordenadorias nos níveis hierárquicos superiores dentro da estrutura do Ministério Público, com o objetivo de traçar diretrizes gerais e planos macros de atuação da instituição, parecem uma imprescindível saída ${ }^{85}$.

\footnotetext{
${ }^{82}$ O STF tem garantido uma interpretação generosa a respeito de tal princípio. Nesse sentido, garantiu, p. ex., a legitimidade do Ministério Público estadual e do DF em atuar nos tribunais superiores, independente da atuação do MPF, quando o processo originário for de sua atribuição, atuação independente (TEMA 946 de Repercussão Geral) e de membro do Ministério Público defender posição contrária aquela adotada por seu antecessor, posteriormente substituído (STF, RE 590908 RG, Relator Min. Ricardo Lewandowski, Relator p/ Acórdão: Min. Marco Aurélio, julgado em 03/11/2011, acórdão eletrônico DJe-112 divulg 08-06-2012 public 11-06-2012 )

${ }^{83}$ Segundo a autora, op. cit., p. 148: "Do ponto de vista político, há crescente rejeição à atuação considerada excessiva ou personalista de alguns membros do Ministério Público que adotam iniciativas típicas de agentes investidos de legitimação política, requisito que o parquet não detém. Argumenta-se que essas iniciativas visam preencher 'vazios' deixados pela autoridade política e administrativa. Mas o fato é que as vitorias judiciais têm sido relativamente modestas, em comparação com a expectativa criada. Esse problema decorre, em parte, da estruturação do Ministério Público. Em virtude da 'captura política' que havia no passado, a Constituição de 1988 optou por um modelo de autonomia e independência funcional praticamente absoluta, por emulação direta das condições dos juízes. Não há hierarquia em relação às chefias, o que previne, até certo ponto, a manipulação política do direito de ação e intervenção ampliados com os novos instrumentos. Contudo, isso gerou um 'vácuo de coordenação' no âmbito interno do Ministério Público, com a pulverização de ações ancoradas muitas vezes exclusivamente na visão pessoal do autor-promotor, nem sempre relevantes ao que seria de esperar em termos de controle de políticas públicas".

${ }^{84}$ Ibid., p. 148.

${ }^{85}$ Dispõe o art. 62 da LC 75/93: Art. 62. Compete às Câmaras de Coordenação e Revisão: I - promover a integração e a coordenação dos órgãos institucionais que atuem em ofícios ligados ao setor de sua competência, observado o princípio da independência funcional; II - manter intercâmbio com órgãos ou entidades que atuem em áreas afins; [...]
} 
Revista Eletrônica de Direito Processual - REDP.

Rio de Janeiro. Ano 13. Volume 20. Número 1. Janeiro a Abril de 2019

Periódico Quadrimestral da Pós-Graduação Stricto Sensu em Direito Processual da UERJ

Patrono: José Carlos Barbosa Moreira (in mem.). ISSN 1982-7636. pp. 250-287

www.redp.uerj.br

\section{NECESSIDADE DE ALTERAÇÕES DA LEGISLAÇÃO PROCESSUAL E CRIAÇÃO DE UM RITO ESPECIAL PARA AS AÇÕES COLETIVAS QUE BUSCAM EXERCER O CONTROLE SOBRE AS POLÍTICAS PÚBLICAS}

Diante das dificuldades e limitações acima apontadas, algumas medidas parecem pertinentes a fim de se buscar dar sequência ao sistema de tutela coletiva de direitos, pertinente ao controle jurisdicional de políticas públicas ${ }^{86}$.

Inicialmente, deve-se destacar a ausência de respostas perfeitas e acabadas para problemas relativamente recentes, como apontados nos capítulos anteriores, eis que decorrem da eclosão de uma realidade relativamente nova, em que o judiciário tem sido chamado a controlar e intervir sobre as políticas públicas, sobretudo nas últimas décadas ${ }^{87}$. Diante de tal realidade, necessário se faz a busca de apontamento de caminhos processuais que se apresentam viáveis diante do contexto apresentado ${ }^{88}$.

O que se aparenta mais premente para a superação das dificuldades apontadas no capítulo anterior diz respeito à criação de regras processuais específicas e que leve em consideração as peculiaridades do controle jurisdicional de políticas públicas, em especial quando tal controle se dá por meio de uma ação coletiva ${ }^{89}$. Por esse motivo, o presente capítulo se concentrará em apontar alguns dos aspectos que uma medida legislativa deveria observar ao criar esse rito processual especial.

De forma concreta, a referida legislação processual deveria abordar, imprescindivelmente, as seguintes temáticas:

i) Definição clara das fases processuais, que garantam uma ampla participação dos entes públicos e da sociedade.

Nesse tópico, diante da relevância das demandas, e da complexidade que as matérias possuem, há necessidade de concessão de prazos substancialmente maiores àqueles previstos na legislação processual civil, a fim de se permitir um amplo debate entre os interessados ${ }^{90}$.

\footnotetext{
${ }^{86}$ ZAVASCKI, op. cit., p. 37: "Foi o legislador brasileiro, na verdade, que protagonizou, de modo muito mais profundo e mais rico do que nos demais países do civil law, a 'revolução' mencionada por Capelletti e Garth, em prol da criação de instrumentos de tutela coletiva".

${ }^{87}$ Ibid., p. 27: "O tempo, a experimentação, o estudo e, eventualmente, os ajustes legislativos necessários, sem dúvida farão dos mecanismos de tutela coletiva uma via serena de aperfeiçoamento da prestação da tutela jurisdicional".

${ }^{88}$ FISS, op. cit., p. 29-30.

${ }^{89}$ BUCCI, op. cit., p. 150: "Curiosamente, pode-se dizer que o problema que a judicialização das políticas públicas hoje enfrenta decorre da falta de procedimento e não de excesso deste".

${ }^{90}$ Ibid., p. 151. Cf., também, RODRIGUES, Marco Antonio. Aspectos processuais do controle jurisdicional de políticas públicas. Revista Brasileira de Advocacia Pública - RBAP, Belo Horizonte, ano 3, n. 4, jan./jun.
} 
Revista Eletrônica de Direito Processual - REDP.

Rio de Janeiro. Ano 13. Volume 20. Número 1. Janeiro a Abril de 2019

Periódico Quadrimestral da Pós-Graduação Stricto Sensu em Direito Processual da UERJ

Patrono: José Carlos Barbosa Moreira (in mem.). ISSN 1982-7636. pp. 250-287

www.redp.uerj.br

A par da ampliação dos debates, a permissão de ingresso dos mais diversos setores da sociedade que tenham interesse, ainda que indireto, na demanda. $\mathrm{O}$ juiz deve ter um papel ativo nesse contexto, convidando associações, agências públicas e outros, para o enriquecimento dos debates ${ }^{91}$.

A iniciativa ora apresentada permitiria, da mesma forma, o exercício de maiores controles sociais sobre a função jurisdicional, justificável diante do impacto social da atuação judicial nesse tipo de demanda ${ }^{92}$.

ii) Delimitação e limitação a alguns juízos da competência jurisdicional para tratar de demandas coletivas impactantes sobre as políticas públicas ${ }^{93}$. Medida que viesse a observar tal preocupação traria maior segurança jurídica à atuação da administração pública e garantiria maiores chances de atendimento dos reclamos sociais de forma compatível com as possibilidades do Estado. Ademais, a redução dos juízos competentes permitiria uma maior especialização por parte desses, com maiores ganhos de eficiência.

iii) Possibilidade de reunião, perante um mesmo juízo, das ações coletivas impactantes sobre as políticas públicas, bem como daquelas individuais que se encontram aforadas perante os mais diversos juízos em uma região, estado ou por todo o país ${ }^{94}$. O sistema deve, assim, poder coletivizar demandas inicialmente individuais, diante, sobretudo, das dificuldades se operacionalizar de forma individual as políticas públicas, bem como diante das limitações orçamentárias impostas à administração pública ${ }^{95}$.

Tal medida permitiria uma solução com melhores resultados e uma maior harmonização da intervenção judicial e o planejamento global da administração pública, na gestão da política pública sob debate.

2017. Disponível em: <http://www.bidforum.com.br/PDI0006.aspx?pdiCntd=247834>. Acesso em: 27 mar. 2018 , p. 109.

${ }^{91}$ FISS, op. cit., p. 21-22.

92 PASSOS, op. cit., p. 117.

93 “COMPARATO, op. cit., p. 47.

${ }^{94}$ Comparato, op. cit., p. 47, aponta preocupação com o espraiamento por milhares de órgãos jurisdicionais do poder de intervenção sobre as políticas públicas: "Por via de lógica consequência, esse juízo de constitucionalidade, ao contrário do que tem por objeto leis ou outros atos normativos, deveria ser concentrado e não difuso. O órgão judiciário competente para proferi-lo haveria de ser, com exclusividade, aquele colocado na cúpula do sistema, em cada nível da estrutura federativa, admitindo-se que, em se tratando de políticas municipais, a competência de processo e julgamento caberia ao Tribunal de Justiça do Estado onde se encontra o Município em questão. Cf., também, RODRIGUES, op. cit., 108. O autor, no texto, demonstra a preocupação com a dispersão de ações individuais sobre políticas públicas.

${ }^{95}$ RODRIGUES, op. cit., p. 108. 
Revista Eletrônica de Direito Processual - REDP.

Rio de Janeiro. Ano 13. Volume 20. Número 1. Janeiro a Abril de 2019

Periódico Quadrimestral da Pós-Graduação Stricto Sensu em Direito Processual da UERJ

Patrono: José Carlos Barbosa Moreira (in mem.). ISSN 1982-7636. pp. 250-287

www.redp.uerj.br

Da mesma forma, tal solução permitiria uma atuação mais coordenada e com menor dispêndio do Ministério Público e outras funções essenciais à justiça.

iv) Contemplação de um conceito mais ampliado de jurisdição, nos termos propostos por Ada Pellegrini Grinover, que afirma, em recente obra, que aquele conceito jurídico "[...] compreende a justiça estatal, a justiça arbitral e a justiça consensual [...]"96 e que, nessa perspectiva, dentro desse novo sistema de controle jurisdicional sobre políticas públicas, seja priorizada a justiça consensual e arbitral.

Nesse sentido, as partes (poder público e sociedade) devem ser incentivadas a solucionar os conflitos, ainda que extrajudicialmente ${ }^{97}$. Para casos em que se mostra possível essa composição, o sistema processual deve permitir, de forma clara, a existência de instrumentos que permitam que o processo judicial reste sobrestado por prazos compatíveis com aqueles exigíveis pela atuação administrativa, em caso em que a solução negociada possa ser alcançada pelos interessados.

v) Outra preocupação que deve orientar a formação de um novo diploma voltado ao controle judicial de políticas públicas, em especial em âmbito de tutela coletiva, consiste na criação de um procedimento mais flexível de cumprimento das sentenças que reconheçam a obrigação do poder público em garantir os direitos fundamentais, não limitado apenas às restritas modalidades atualmente existentes, que, em regra, possuem rito abreviado e de caráter impositivo ao devedor.

Nesse sentido, afirma Marco Antônio Rodrigues:

$\mathrm{Na}$ execução de sentença que impacte de alguma forma uma política pública, fundamental se faz que o juiz, da mesma forma que na fase de conhecimento, confira ampla possibilidade de que as partes influenciem seu convencimento quanto aos limites e modo de efetivação da obrigação imposta na sentença. Tem-se aqui, em nome da cooperação, uma execução compartilhada entre os sujeitos do processo ${ }^{98}$.

\footnotetext{
${ }^{96}$ GRINOVER, op. cit., p. 62.

97 Sobre a Câmara de Conciliação no âmbito da Advocacia-Geral da União, vide BERNARDO, Leandro Ferreira. A câmara de conciliação e o novo papel da Advocacia-Geral da União. Revista da AGU, v. 25, p. 163-184, 2010.

${ }^{98}$ RODRIGUES, op. cit., p. 112.
} 
Revista Eletrônica de Direito Processual - REDP.

Rio de Janeiro. Ano 13. Volume 20. Número 1. Janeiro a Abril de 2019

Periódico Quadrimestral da Pós-Graduação Stricto Sensu em Direito Processual da UERJ

Patrono: José Carlos Barbosa Moreira (in mem.). ISSN 1982-7636. pp. 250-287

www.redp.uerj.br

A sugerida adequação se justifica à medida em que se observa os desafios de implementação ou expansão de políticas públicas pelo poder pública. Muitas vezes a sua efetivação de forma açodada imporá a alocação, de forma desorganizada, de verbas orçamentárias relevantes, com a consequente alteração de prioridades da pasta. Por consequência, ter-se-á novo impacto sobre a coletividade que vê frustrada sua expectativa de direitos após as mudanças impostas pelo judiciário.

vi) Deve ser, da mesma forma, objeto de preocupação desse novo sistema de tutela coletiva de políticas públicas a existência de um controle gerencial sobre as demandas, coletivas e individuais, que buscam o exercício de controle sobre as políticas públicas, com a construção de um acervo dos casos levados ao judiciário em todo o país. Tais dados poderiam auxiliar para fins estatísticos e de planejamento dos entes públicos e do judiciário, na consolidação de precedentes jurisprudenciais, dentre outros ${ }^{99}$.

Cumpre apontar que tramita no Congresso Nacional atualmente Projeto de Lei sob o número 8.058, de 2014, de autoria e que, em grande medida, busca contemplar as preocupações e proposições ora apresentadas. Embora esteja sujeito a melhorias, o referido projeto traça importante caminho para o aprimoramento no controle e intervenção em políticas públicas pelo Poder Judiciário ${ }^{100}$.

\section{CONCLUSÕES}

Em que pese o aprofundamento dos debates envolvendo os limites da intervenção do judiciário sobre as políticas públicas nos últimos anos, o aspecto processual de tal tutela ainda não tem tido uma detida atenção por parte da doutrina e do legislador ${ }^{101}$.

A preocupação com a forma com que se dá prestação judicial merece especial destaque quando se está diante daquele controle sobre políticas públicas, a fim de se garantir uma atuação imparcial, embasada em conhecimento técnico, e que permita o efetivo e adequado

\footnotetext{
${ }^{99}$ BUCCI, op. cit., p. 241.

100 É possível apontar diversas críticas ao projeto, como: (i) a fixação, já em seu capítulo I, de regras interpretativas de direito e princípios de direito material aplicáveis no controle de políticas públicas pelo Poder Judiciário; ii) tratamento inadequado dos meios alternativos de solução de controvérsias, que desconsidera a existência de ente público e das normas que os regem, bem como despreza a experiência já existente em outras legislações para a conciliação de demandas envolvendo o poder público, como no caso da Câmara de Conciliação e Arbitragem da Administração Federal; iii) previsão de capitulo sobre "Relações entre Magistrados", para fomentar, dentre outras coisas, reuniões entre juízes, a fim de buscar uma harmonização de entendimentos, eis que tal preocupação deve ser direcionada aos órgãos de gestão do judiciário, em especial o CNJ.

${ }^{101}$ PASSOS, op. cit., p. 71.
} 
Revista Eletrônica de Direito Processual - REDP.

Rio de Janeiro. Ano 13. Volume 20. Número 1. Janeiro a Abril de 2019

Periódico Quadrimestral da Pós-Graduação Stricto Sensu em Direito Processual da UERJ

Patrono: José Carlos Barbosa Moreira (in mem.). ISSN 1982-7636. pp. 250-287

www.redp.uerj.br

atingimento da política pública aos seus destinatários finais, determinados pelo Poder

Constituinte e pelo legislador, sem que para tanto seja necessária, pura e simplesmente, a substituição da figura do administrador pela do juiz ${ }^{102}$.

Não se pode deixar de apontar que em uma sociedade estável e em que os poderes constituídos observam os ditames do sistema normativo, não deveria haver espaço para um distanciamento considerável entre a atuação da administração pública e aquela buscada perante o judiciário. Nesse sentido, adverte Calmon de Passos que "contradição entre eles [os poderes ou funções estatais], salvo sobre filigranas, é denunciadora de crise de governabilidade, de instabilidade ou de mudança de paradigma" 103 .

Não parece fugir a essa lógica o caso da realidade brasileira. Embora seja ainda presente o déficit do poder público em implementar os direitos fundamentais previstos na Constituição da República em favor da população e a existência de recorrentes dificuldades institucionais ainda não sanadas, vivemos em um Estado Democrático de Direito, constituído por instituições públicas perenes, e, nesse sentido, a busca de uma conciliação entre as políticas públicas engendradas pelo legislador e administrador e a atuação do judiciário naquela espécie de demanda deve ser uma constante.

A preocupação com o estabelecimento de um rito processual adequado pode representar um importante caminho na busca de uma segura implementação dos direitos fundamentais, sobretudo no âmbito da tutela coletiva de direitos ${ }^{104}$.

\section{REFERÊNCIAS BIBLIOGRÁFICAS:}

\section{AGU - ADVOCACIA-GERAL DA UNIÃO. Advocacia-Geral consegue suspender decisão que causaria desequilíbrio orçamentário. Disponível em: <http://www.agu.gov.br/page/content/detail/id_conteudo/646404>. Acessado em: 21 fev. 2018.}

\footnotetext{
102 GRINOVER, op. cit., p. 128: "Mesmo quando exerce o controle de atos administrativos, por exemplo, o juiz jamais pode substituir-se ao administrador".

103 PASSOS, op. cit., p. 70.

${ }^{104}$ SILVA, Virgílio Afonso da. O Judiciário e as políticas públicas: entre transformação social e obstáculo à realização dos direitos sociais, p. 592: "Embora muitos autores façam um grande esforço para demonstrar 'histórias de sucesso' na efetivação de direitos sociais por meio do Judiciário, parece-me que tais histórias são superestimadas, da mesma forma que o é o papel que o Judiciário desempenha nessa área. Da mesma forma que a conquista de direitos civis e políticos foi uma conquista da sociedade civil, efetivada por meios políticos, a implementação de direitos sociais e econômicos não vai ser realizada de forma diversa".
} 
Revista Eletrônica de Direito Processual - REDP.

Rio de Janeiro. Ano 13. Volume 20. Número 1. Janeiro a Abril de 2019

Periódico Quadrimestral da Pós-Graduação Stricto Sensu em Direito Processual da UERJ

Patrono: José Carlos Barbosa Moreira (in mem.). ISSN 1982-7636. pp. 250-287

www.redp.uerj.br

AGU derruba decisão que determinava a divulgação das provas de redação de

todos os participantes do Enem. Disponível em:

http://www.agu.gov.br/page/content/detail/id_conteudo/223913. Acessado em: 12 mar. 2018.

ARENHART, Sergio Cruz. As ações coletivas e o controle das políticas públicas pelo

Poder Judiciário. In: Revista Eletrônica do Ministério Público Federal, I. Disponível em: http://www.prrj.mpf.mp.br/custoslegis. Acessado em: 02 mar. 2018.

ARENHART, Sérgio Cruz. Decisões estruturais no processo civil brasileiro. 2013. Disponível em: <www.academia.edu>. Acessado em: 02 mar. 2018.

BARBOZA, Estefânia Maria de Queiroz \& KOZICKI, Katya. Judicialização da política e controle judicial de políticas públicas. Revista Direito GV, [S.1.], v. 8, n. 1, p. 059085, jan. 2012. ISSN 2317-6172. Disponível em: <http://bibliotecadigital.fgv.br/ojs/index.php/revdireitogv/article/view/23970/22728> . Acesso em: 01 mar. 2018.

BAUMAN, Zygmunt. O mal-estar da pós-modernidade. Tradução: Mauro Gama, Cláudia Martinelli Gama. Rio de Janeiro: Zahar, 1998.

BITTAR, Eduardo C. B. O direito na pós-modernidade. 3. ed. modificada e atualizada. São Paulo: Atlas, 2014.

BRASIL. CAMARA DOS DEPUTADOS. PROJETO DE LEI 8.058, de 2014. Disponível em: http://www.camara.gov.br/sileg/integras/1284947.pdf. Acessado em: 20 fev. 2018.

BUCCI, Maria Paula Dallari. Fundamentos para uma teoria jurídica das políticas públicas. São Paulo: Saraiva, 2013.

CANOtilho, J. J. Gomes. Direito Constitucional e Teoria da Constituição. 7. ed. Coimbra: Almedina, 1997.

CARDOSO, Fernando Henrique. Capitalismo e escravidão no Brasil meridional: o negro na sociedade escravocrata do Rio Grande do Sul. Rio de Janeiro: Civilização Brasileira, 2003.

CNJ - Conselho Nacional de Justiça. 100 maiores litigantes. Disponível em: $<$ http://www.cnj.jus.br/images/pesquisasjudiciarias/pesquisa_100_maiores_litigantes.pdf>. Acessado em: 10 jul. 2011. 
Revista Eletrônica de Direito Processual - REDP.

Rio de Janeiro. Ano 13. Volume 20. Número 1. Janeiro a Abril de 2019

Periódico Quadrimestral da Pós-Graduação Stricto Sensu em Direito Processual da UERJ

Patrono: José Carlos Barbosa Moreira (in mem.). ISSN 1982-7636. pp. 250-287

www.redp.uerj.br

\section{_. Justiça em números 2017: ano base 2016. Disponível em: < http://www.cnj.jus.br/programas-e-acoes/pj-justica-em-numeros >. Acessado em: 21 mar. 2018.}

. Levantamento dos Presos Provisórios do País e Plano de Ação dos Tribunais.

Disponível em: <http://www.cnj.jus.br/noticias/cnj/84371-levantamento-dos-presosprovisorios-do-pais-e-plano-de-acao-dos-tribunais>. Acessado em: 28 mar. 2018.

. Ministério da Saúde alerta sobre custos da judicialização. Disponível em: http://www.cnj.jus.br/noticias/cnj/85915-ministerio-da-saude-alerta-sobre-custos-dajudicializacao. Acessado em: 21 mar. 2018.

COMPARATO, Fábio Konder. Ensaio sobre o juízo de constitucionalidade de políticas públicas. In: Revista de Informação Legislativa, Brasília a. 35 n. 138 abr.jun. 1998. Disponível em: 〈http://www2.senado.leg.br/bdsf/>. Acesso em: 24 jan. 2017.

CUNHA, Manuela Carneiro da. História dos índios no Brasil. São Paulo: Companhia das Letras; Secretaria Municipal de Cultura; FAPESP, 1992.

DALLARI, Direitos humanos e cidadania. 2. ed. reform. São Paulo: Moderna, 2004.

FERNANDES, Florestan. O negro no mundo dos brancos. 2. ed. revista. São Paulo: Global, 2007.

FERRARO, Marcella Pereira. Do processo bipolar a um processo coletivo-estrutural. 2015. 224 f. Dissertação (Mestrado em Direito das Relações Sociais) - Universidade Federal do Paraná, Curitiba, 2015. Disponível em: <https://acervodigital.ufpr.br/handle/1884/39322>. Acessado em: 21 mar. 2018.

FISS, Owen. The law as It could be. New York and London: New York University Press, 2003.

GRAU, Ero Roberto. Por que tenho medo de juízes: (a interpretação/aplicação do direito e os princípios). 8. ed. refundida do Ensaio e discurso sobre a interpretação/aplicação do direito. São Paulo: Malheiros, 2017.

GRINOVER, Ada Pellegrini. Ensaio sobre a processualidade: fundamentos para uma nova teoria geral do processo. Brasília/DF: Gazeta Jurídica, 2016.

HARVEY, David. Condição pós-moderna: Uma pesquisa sobre as origens da mudança cultural. Tradução: Adail Ubirajara Sobral; Maria Stela Gonçalves. Edições Loyola: São Paulo, 2009. 
Revista Eletrônica de Direito Processual - REDP.

Rio de Janeiro. Ano 13. Volume 20. Número 1. Janeiro a Abril de 2019

Periódico Quadrimestral da Pós-Graduação Stricto Sensu em Direito Processual da UERJ

Patrono: José Carlos Barbosa Moreira (in mem.). ISSN 1982-7636. pp. 250-287 www.redp.uerj.br

HOBSBAWM, Eric J. Nações e nacionalismo desde 1780: programa, mito e realidade.

Tradução: Maria Celia Paoli \& Anna Maria Quirino. Rio de Janeiro: Paz e Terra, 1990.

MARINONI, Luiz Guilherme \& ARENHART, Sergio Cruz. Manual do processo de conhecimento. 5. Ed. rev., atual. e ampl. São Paulo: Revista dos Tribunais, 2006.

PASSOS, José Joaquim Calmon de. Direito, poder, justiça e processo: julgando os que nos julgam. Rio de Janeiro: Forense, 2000.

PONTES DE MIRANDA, Francisco C. Comentários à Constituição de 1967 com a emenda n. 1, de 1969. Tomo IV (arts. 118-153, § $1^{\circ}$ ). São Paulo: Editora Revista dos Tribunais, 1970 .

RODRIGUES, Marco Antonio. Aspectos processuais do controle jurisdicional de políticas públicas. Revista Brasileira de Advocacia Pública - RBAP, Belo Horizonte, ano 3, n. 4, jan./jun. 2017. Disponível em: <http://www.bidforum.com.br/PDI0006.aspx?pdiCntd=247834>. Acesso em: 27 mar. 2018.

SARLET, Ingo Wolfgang. A eficácia dos direitos fundamentais. 6. ed. Ver. atual, e ampl. Porto Alegre: Livraria do Advogado Editora; 2006.

SILVA, Virgílio Afonso da. Interpretação constitucional e sincretismo metodológico. In: (Org.). Interpretação constitucional. São Paulo: Malheiros, 2005, p. 115143.

. O Judiciário e as políticas públicas: entre transformação social e obstáculo à realização dos direitos sociais. In: Cláudio Pereira de Souza Neto \& Daniel Sarmento, Direitos sociais: fundamentação, judicialização e direitos sociais em espécies, Rio de Janeiro: Lumen Juris, 2008: 587-599.

STRECK, Lênio Luiz. Hermenêutica jurídica e(m) crise: uma exploração hermenêutica da construção do direito. 7. ed. rev. e atual. Porto Alegre: Livraria do Advogado Editora, 2007.

ZAVASCKI, Teori Albino. Processo coletivo: tutela de direitos coletivos e tutela coletiva de direitos. São Paulo: Editora Revista dos Tribunais, 2006. 